\title{
Phytolith analyses from Khil and Kaf Taht el-Ghar (Western Maghreb): Plant use trajectories in a long-term perspective
}

\author{
Carla Lancelotti ${ }^{\text {a,b,c, }}$, Rafael M. Martínez Sánchez ${ }^{\mathrm{d}}$, Juan Carlos Vera Rodríguez ${ }^{\mathrm{e}}$, \\ Guillem Pérez-Jordà ${ }^{\mathrm{f}}$, Leonor Peña-Chocarro ${ }^{\mathrm{g}}$, Stefano Biagetti ${ }^{\mathrm{a}, \mathrm{c}, \mathrm{h}}$, Marco Madella ${ }^{\mathrm{a}, \mathrm{b}, \mathrm{c}, \mathrm{h}}$ \\ ${ }^{a}$ CaSEs - Culture and Socio-Ecological Dynamics, Department of Humanities, Universitat Pompeu Fabra, Barcelona, Spain \\ ${ }^{\mathrm{b}}$ ICREA, Passeig Lluís Companys 23, Barcelona, Spain \\ ${ }^{\mathrm{c}}$ Institución Milà y Fontanals, Departamento de Arqueología y Antropología (CSIC), Barcelona, Spain \\ d Dept. Historia, Facultad de Filosofía y Letras, Universidad de Córdoba. 14071 Córdoba, Spain \\ e Dept. Historia, Geografía y Antropología. Universidad de Huelva, Spain \\ ${ }^{\mathrm{f}}$ GRAM- GIUV2015-222. Dept. de Prehistoria, Arqueologia i $H^{a}$ Antiga. Universitat de Valencia, Spain \\ ${ }^{g}$ Laboratorio Arqueobiología, Instituto de Historia (CSIC), Madrid, Spain \\ h Department of Geography, Archaeology, and Environmental Studies, University of the Witwatersrand, Johannesburg, South Africa
}

\section{A R T I C L E I N F O}

\section{Keywords:}

Phytoliths

Neolithic

Crop-processing

Palm leaves

\begin{abstract}
A B S T R A C T
In this paper we present the results of phytolith investigations at two archaeological sites in northwestern Morocco: Khil (Tangier) and Kaf Taht el-Ghar (Tétouan). The two sites located in Western Maghreb, one on the Atlantic and one on the Mediterranean coast, were investigated in the framework of the AGRIWESTMED project. Phytolith analysis complemented archaeobotanical, geoarchaeological and archaeological investigations to better identify plant use during the entire occupation sequence. At Khil 16 samples have been studied, coming from two profiles excavated in two different caves of the same system - grotte $B$ and grotte $C$ - that span a chronology comprised between the early Neolithic and the historic period. At Kaf Taht el-Ghar, 15 samples were analysed spanning from the Palaeolithic to the Historic period.

Results show that at Khil plants are widely used from the very beginning of the Early Neolithic sequence. The surrounding vegetation was exploited and both C3 and C4 grasses were used, inside the cave. At the same time a wide array of other plants was utilised, such as palms and woody taxa. Phytolith analysis at the site of Kaf Taht el-Ghar indicates that crop processing was most probably not taking place on site. However, the predominance in the samples of C3 grasses morphologies agrees with the finding of previous macro botanical studies that identified cultivated wheat and barley in this cave deposits. A very interesting aspect of the phytolith assemblages of Kaf Taht el-Ghar is the widespread use of palm leaves and their gradual disappearance through time that coincides with an increase in the use of woody species.
\end{abstract}

\section{Introduction}

The northern coast of Africa represents the natural interface between the African continent and the Mediterranean Sea. Stretching from the Atlantic shores of Morocco up to Suez, Mediterranean Africa has been a permeable crossroad between Europe, Asia, and Africa from ancient to present times. Due to its geographical location, western Maghreb - the westernmost section of Mediterranean Africa - holds a prominent position in the deep history of contacts and exchanges between Africa and Europe, well before the historical and modern ages, when the Mediterranean Sea became the crossroads of empires, states, and civilizations (e. g. Broodbank, 2013). Recent studies have highlighted the role of the Maghreb in early prehistory (Sahnouni et al., 2018) and the spread of anatomical modern humans (Hublin et al., 2017). Yet, the overall picture of the transition to food production in the Maghreb is still patchy. In this perspective, fresh research has specifically focused on the Holocene in the Maghreb, investigating the arrival of the first Neolithic communities with cereals and legumes towards the middle of the 6th millennium BC (Ballouche and Marinval, 2003; Morales et al., 2013, 2016; Zapata et al., 2013, Martínez-Sánchez et al., 2018a, 2021). The Tingitana peninsula (where Khil and Kaf Taht el-Ghar are located) is probably one of the best studied areas, with several sites investigated for

\footnotetext{
* Corresponding author.

E-mail addresses: carla.lancelotti@upf.edu (C. Lancelotti),rmmartinez@uco.es (R.M. Martínez Sánchez).
} 
archaeobotanical remains. A recent overview of the state of research on the process of Neolitisation in this part of North Africa, suggests that domesticated crops were introduced from the southern Iberian Peninsula, together with Cardial wares (Martínez-Sánchez et al., 2018b). In this paper we present the results of phytolith analysis and we highlight the trajectories of plant exploitation and use at the sites of Khil and Kaf That el-Ghar, from the Paleolithic to Historic times.

\subsection{Context, environment and chronology of the samples analysed}

The two archaeological sites under study are located in the Tingitana peninsula, the northernmost region of Morocco. Khil is placed on the North Atlantic coast and Kaf Taht el-Ghar next to the Mediterranean shore (Fig. 1). At both sites the prevalent climate is Mediterranean with oceanic influences, with the highest rainfall between October and March and frequent dry spells during summer. The Aridity Index (Tabucco and Zomer, 2019; Zomer et al., 2007, 2008) at both sites is c. 0.55 defining the environment as dry sub-humid. Thus, today the prevalent vegetation at both sites is the maquis-forest (Morales et al., 2016 and references therein).

Nowadays, North Africa is much drier than it was in the Early and Middle Holocene, when the environment was more humid and 'green'. Different proxies point to climatic oscillations that determined changes in both sea-level and vegetation, variably affecting ancient human societies (DeMenocal, 2001; Kuper and Kröpelin, 2006; Clarke et al., 2016). Sea level varied considerably from the Last Glacial Maximum (c. 23-20kya), when the sea was up to $130 \mathrm{~m}$ lower than by $4000-3000$ BCE, when it reached its current level (e.g, Benjamin et al., 2017). Shifts in sea-level reflect more general climatic trends that affected North Africa throughout the Holocene. Yet, along with regional environmental dynamics, local phenomena must have played an important role and need to be considered as well, since the physiography of specific setting (e.g., mountains, oases) might have shaped local cultural dynamics (e.g. Cremaschi et al., 2014). A recent macro-scale approach has reviewed the available data from the different regions of North Africa and pinpointed three main phases marked by arid spells recorded continentally to better fit social, environmental, and economic information available: Phase 1 from the beginning of the Holocene up to the 6200 cal. BC climatic arid spell, characterized by warm climate and by a foraging economy based also on marine resources; Phase 2 - from 6200 to c. 4000 cal. BC, when the spread of domesticates from the Near East rapidly reached the Maghreb following the onset of improved environmental conditions; finally Phase 3 - from 4000 to c. 1000 cal. BC, which still remain poorly understood in the Maghreb due to the lack of archaeological stratigraphies, and when the environment turned to present conditions. (Broodbank and Lucarini, 2019, and references therein).

Morocco, especially its eastern portion, has been the focus of several archaeobotanical investigations in recent years. Such investigations have identified the long persistence of a mixed hunter-gatherers-fishers economy even during the Neolithic with no definite presence of domestic plants and animals, contrary to what happens in western Maghreb (Portillo et al., 2020 and references therein). The extensive archaeobotanical analyses of charred macro-remains carried out at the sites of Khil and Kaf Taht el-Ghar (Morales et al., 2016) show that cereals (emmer, free-threshing wheat, naked barley), pulses (broad bean) and fruits (grape, mastic tree and myrtle) were being consumed at these sites by $5500-5000$ cal. BC. Similarly, at the site of Ifri n'Amr ou Moussa, wild pulses and fruit of the mastic tree were identified in the Epipaleolithic layers, whereas in the Neolithic phase (dated to $5100 \mathrm{cal}$. BC) seeds of domesticated cereals are found together with seeds and fruit of wild

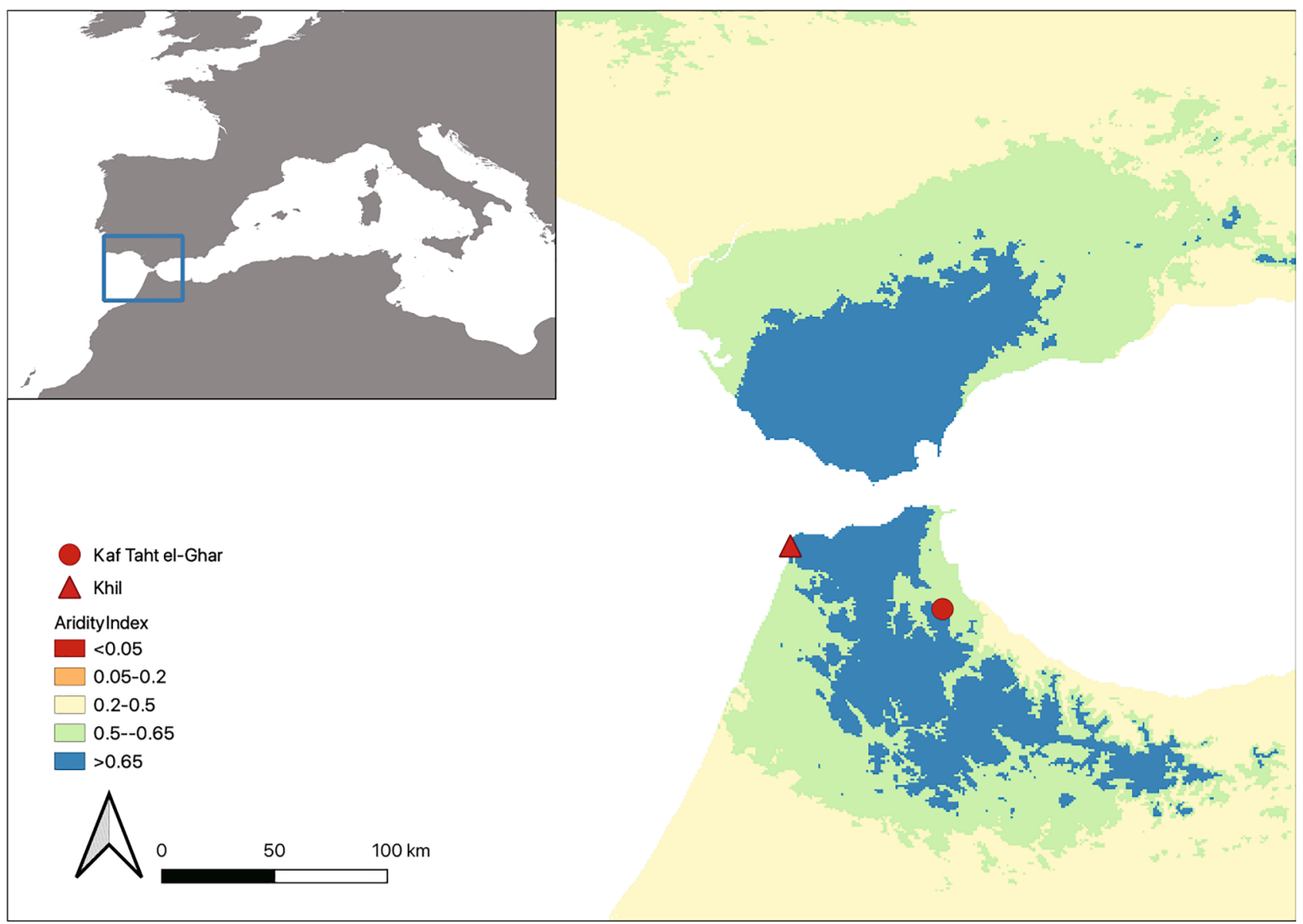

Fig. 1. Location of the two archaeological sites anlaysed in the present work based on a map of Aridity Index values (data extracted from Zomer et al. 2007, 2008). 


\section{KHIL C 2011 SECTION}

KHIL B 2011 SECTION

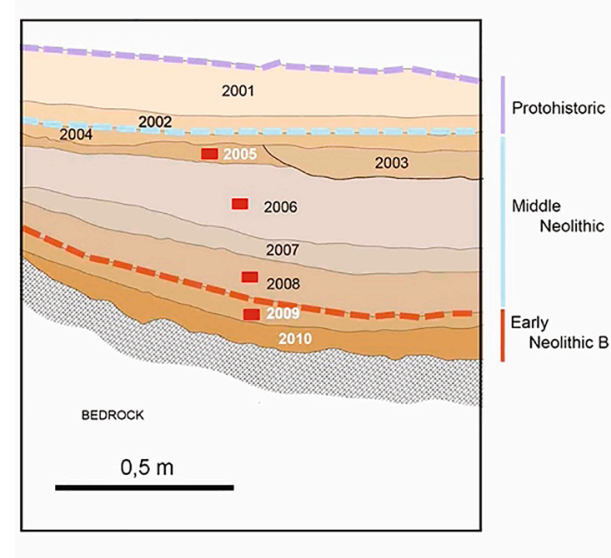

KTG 2012 SECTION
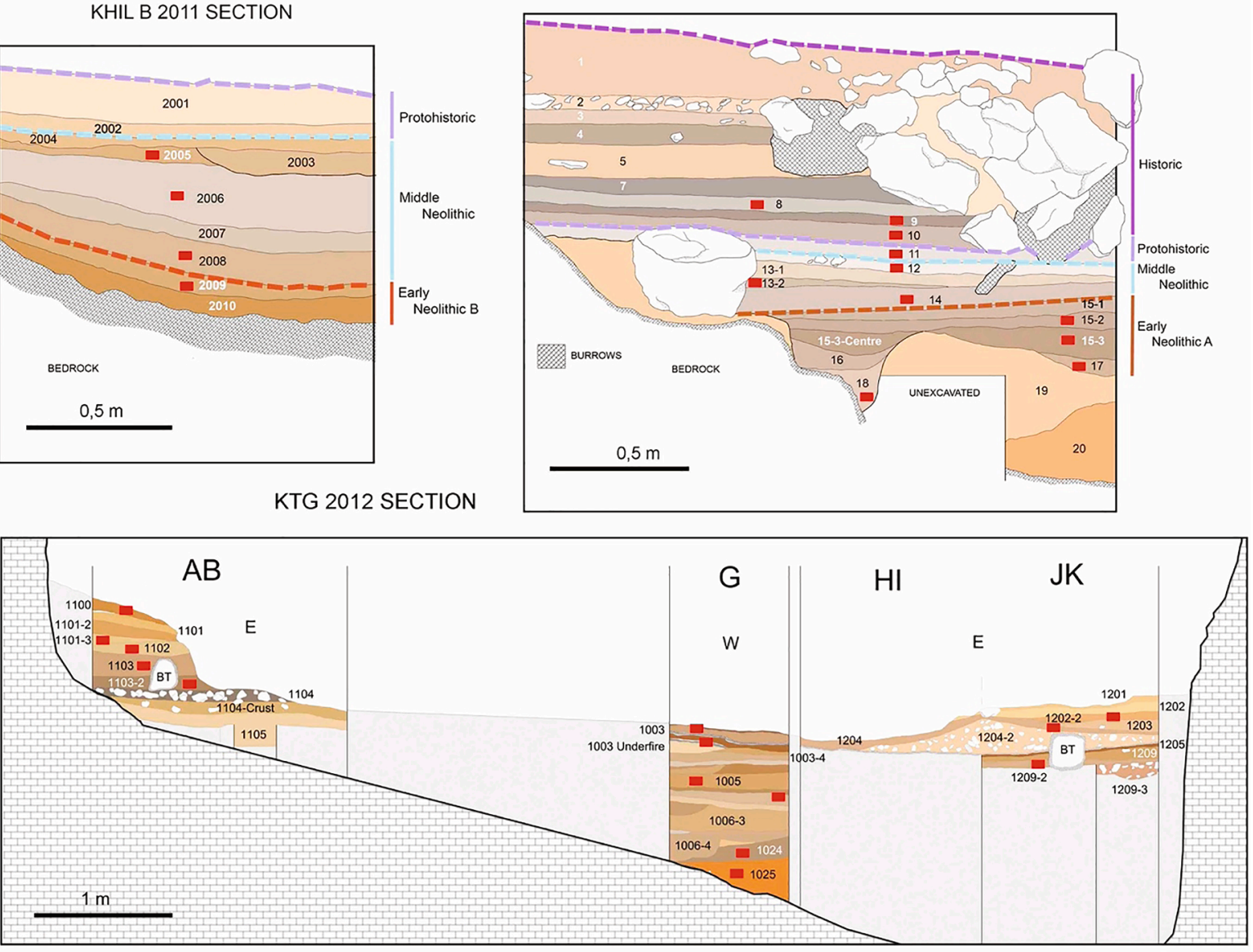

Fig. 2. Stratigraphy of the two sites under study and location of samples analysed. arboreal species (Carrión Marco et al., 2018).

\subsubsection{Khil}

The archaeological site of Khil is composed by a series of caves situated at the end of the Ashakar Wadi, in Tangier province (Figs. 1 and 2). It is a karstic formation where several caves of small dimensions were inhabited, or sporadically used, in the past by small communities of agro-pastoralists, fishers and shell-gatherers. From the archaeological evidence it seems possible to place the beginning of the frequentation of this site in the mid-VI millennium, with a peak during the fifth millennium, and occupation continuing up to historical times (Peña-Chocarro et al., 2012; Martínez-Sánchez et al., 2018b).

In September 2011 a joined team of Spanish and Moroccan archaeologists revisited the site in the framework of a collaborative project between the Spanish National Research Council (CSIC) and the National Institute for the Archaeological and Cultural Heritage Sciences (INSAP). The project aimed at acquiring data to evaluate the role of the first agricultural communities in the area through the systematic analysis of bioarchaeological material (charred seeds and wood, pollen and phytoliths, faunal and micro-faunal remains) collected during the new excavations. On this occasion interventions were carried out in three caves -grotte $\mathrm{B}, \mathrm{C}$ and $\mathrm{D}$ - and systematic samples were collected from the two that showed cultural material corresponding to the Neolithic period, grotte $\mathrm{B}$ and $\mathrm{C}$, in line with the aims of the study. The macro-botanical remains are dominated by broad bean (Vicia faba) and naked wheat (Triticum aestivum/durum) grains (Morales et al., 2016).

Radiocarbon dates on short-lived specimens confirm an Early Neolithic phase dated to c. 5300-5000 cal. BC and a Middle Neolithic phase sated to c. 4500-4000 cal. BC (Martínez-Sánchez et al., 2018a;
Morales et al., 2016). The proposed chronology of the two caves, with correlations between the two sequences can be found in Table 1.

Sixteen samples have been studied, coming from the two profiles (Fig. 2 and Table 1). Four samples from grotte $\mathrm{C}$ belong to the historic period and were analysed as control samples. Of the remaining samples six were dated to the Middle Neolithic period (three from grotte $C$ and three from grotte B) and six to the Early Neolithic (five from grotte $C$ and one from grotte B). All samples were collected from the general deposit of the cave and represent different moments of anthropic occupation.

\subsubsection{Kaf Taht el-Ghar}

The archaeological site of Kaf Taht el-Ghar is located in the province of Tétouan (Figs. 1 and 2). It is a karstic cave, situated in the BéniHosmar massif dominating over the Oued Martil Valley and the Mediterranean coast (Ballouche and Marinval, 2003). The site was studied first in the fifties by a Spanish archaeological mission (Tarradell, 195758) and then in the late eighties by a French-Moroccan archaeological team (Daugas et al., 2008) that established it as one of the oldest Neolithic sites in Northern Africa. Traces of domesticated species, both of plants and animals, were identified in the Early Neolithic levels (Ballouche and Marinval, 2003). The authors found domesticated emmer, einkorn and naked wheat (Triticum dicoccum, T. monococcum and T. aestivum/durum) in a layer dated to the end of the VI millennium Cal BC.

The AGRIWESTMED team revisited the site in 2012 (MartínezSánchez et al., 2018a, 2021) when four profiles were cleaned and sampled for bioarchaeological samples. In this occasion up to 42 stratigraphic units were identified and bulk sediment samples were collected for phytolith analysis from three of the four profiles ( $26 \mathrm{AB}, 26 \mathrm{G}$ and 26 
Table 1

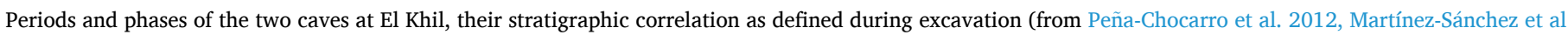

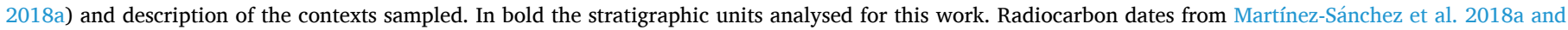
Morales et al. 2016.

\begin{tabular}{|c|c|c|c|c|c|}
\hline & Period & Phase & grotte B & grotte C & \\
\hline & & 1 & & Sterile layers with evidence of bioturbation (s.u. 1, 2) & Sub-actual \\
\hline & & 2 & & $\begin{array}{l}\text { Post Medieval, scarce evidence of occupation; high } \\
\text { bioturbation (s.u. 3) }\end{array}$ & Historic \\
\hline & & 3 & & $\begin{array}{l}\text { Islamic Medieval occupation, marine resource exploitation } \\
\text { (s.u. 4, 5) }\end{array}$ & \\
\hline & & 4 & & Scarce or no human presence (s.u. 6-8) & \\
\hline & & 5 & & $\begin{array}{l}\text { Late Roman occupation with ceramic dated to the IV- V } \\
\text { centuries AD (s.u. 9) }\end{array}$ & \\
\hline Abandonment & 1 & 6 & & $\begin{array}{l}\text { Transition between prehistoric and historic periods (s.u. } \\
\text { 10) }\end{array}$ & Abandonment \\
\hline Late prehistory & 2 & 7 & Protohistoric occupation (s.u 2001, 2002) & $\begin{array}{l}\text { Recent prehistory, sporadic use, possible funerary use (s.u. } \\
\text { 11) }\end{array}$ & LatePrehistory \\
\hline Neolithic & 3 & 8 & $\begin{array}{l}\text { Post-depositional erosion processes (s.u. 2003). Intense } \\
\text { occupation with Ashakar ware and abundant marine } \\
\text { resources (s.u. 2004, 2005, 2006, 2007, 2008)5490 } \pm 40 \\
\text { (Beta 316505); 5420 } \pm 40 \text { (Beta 316506) }\end{array}$ & $\begin{array}{l}\text { Frequent occupation with characteristic Neolithic material } \\
\text { (both lithic and ceramic) and remains of domesticated } \\
\text { crops and animals (s.u. 12,13,14)5450 } \pm 40 \text { (Beta 316507); } \\
5470 \pm 40 \text { (Beta 316508) }\end{array}$ & MiddleNeolithic \\
\hline $\begin{array}{l}\text { Early Neolithic } \\
\quad \text { B }\end{array}$ & 4 & 9 & $\begin{array}{l}\text { Beginning of the occupation of grotte B, with non Cardial } \\
\text { impressions and with evident signs of marine resources } \\
\text { exploitation(s.u. 2009, 2010)5790 } \pm 30 \text { (Beta 331845) }\end{array}$ & & EarlyNeolithic \\
\hline $\begin{array}{l}\text { Early Neolithic } \\
\text { A }\end{array}$ & 4 & 10 & & $\begin{array}{l}\text { Cardial impressions and channelled ware (s.u. 15, 16, 17, } \\
\text { 18) } 6180 \pm 50 \text { BP (Beta-295780) }\end{array}$ & \\
\hline Natural layer & & & & $\begin{array}{l}\text { Alteration of the natural rock by biological agents and } \\
\text { weathering. S.u. } 19 \text { contains large quantity of fossil } \\
\text { malacofauna and lays on sterile sand u.s } 20\end{array}$ & Geologic \\
\hline
\end{tabular}

JK, see Martínez-Sánchez et al., 2021 for the full description of the excavation material and methods and details on the excavated trenches). For the present work, 16 samples were processed of which only 15 were then used for analysis (Fig. 2 and Table 2). One sample was excluded because of the few phytoliths observed, which all belonged to categories that are not taxonomically significant. All the fifteen samples analysed come from the anthropogenic sediment of the cave, from layers of occupational deposition. Two of them were collected from fireplaces and were studied separately as they represent different types of deposits that involve specific strategies of plant use. The other samples examined cover the entire chronological sequence from the Palaeolithic to Historic periods.

\section{Material and methods}

A total of 31 samples were analysed: 16 from Khil and 15 from Kaf Taht el-Ghar covering the entire chronology of occupation at both sites (see Tables 1, 2 for samples description and Tables 3 and 4 for details on phytoliths). Samples were collected from recently excavated sections at both sites. Phytoliths were extracted from bulk sediment samples following the procedure described by Madella et al., (1998) slightly modified to calculate the AIF (Acid-Insoluble Fraction, Albert and Weiner, 2001) and to adapt to recent studies about the aggressive effect of too concentrated chemicals and long times of exposure (Cabanes et al., 2011). The sediment was dried in a drying cabinet until no loss of weight was recorded, then 4 to $5 \mathrm{~g}$ of material were subsampled for analysis. The full protocol used for extraction as well as raw data can be found in the Supplementary Material (SM1, SM2 and SM3) and are stored on GitHub.

Phytolith were mounted in permanent medium and observed under transmitted light microscope with magnification between 20X and 40X. Phytoliths were counted up to 300 identified individual morphotypes or, when not possible, the full slide was scanned. Identification was based on published reference material, such as thePhytCore database (2021)

Table 2

Periods and phases of the excavated trenches at Kef That el Ghar, their stratigraphic correlation and dating as defined during excavation, and description of the contexts sampled (from Martínez-Sánchez et al., 2021 and references therein). In bold the stratigraphic units analysed for this work.

\begin{tabular}{|c|c|c|c|c|}
\hline & Phase & $26 A B / 26 A B$ ext & $26 G$ & $26 \mathrm{HI} / 26 \mathrm{JK}$ \\
\hline Historic & 1 & $\begin{array}{l}\text { Long phase that c } \\
\text { s.u. 1100, } 1100 \mathrm{~h} \\
1101-1,1101-2\end{array}$ & edieval wheel-made pottery alongside some later prehistory potsherds. & s.u.1201 \\
\hline $\begin{array}{l}\text { Middle } \\
\text { Neolithic }\end{array}$ & 2 & \multicolumn{3}{|c|}{$\begin{array}{l}\text { The most recent of the prehistoric sequences, shows a less intense occupation and is dated c. } 4200 \text { cal. BC. Identified plant remains include naked wheat } \\
\text { (Triticum aestivum/durum), legumes (Lathyrus/Vicia) and fruits (Pistacia lentiscus and Vitis vinifera). }\end{array}$} \\
\hline Early Neolithic & 3 & \multicolumn{3}{|c|}{$\begin{array}{l}\text { The richest phase in terms of material culture and plant and animal remains, dated between } 5500 \text { and } 5100 \text { cal. BC. Identified plant remains include } \\
\text { cereals (Triticum diccocum, T. aestivum/durom, Hordeum vulgare), legumes (Lathyrus/Vicia sspp.) and fruits (Vitis vinifera and Myrtus communis). }\end{array}$} \\
\hline Transition & 4 & Period of abandonment or very low frequentation of the cave, dated between 6200 and $5500 \mathrm{cal} . \mathrm{BC}$. & $\begin{array}{l}\text { ery low frequentation of the cave, dated between } 6200 \text { and } 5500 \text { cal. BC. } \\
\text { s.u. } 1003 \text { Crust }\end{array}$ & s.u.1205 \\
\hline Epipaleolithic & 5 & $\begin{array}{l}\text { This phase consist } \\
\text { cal. BC. It yielded } \\
\text { s.u. } 1104 \text { concretic } \\
1105\end{array}$ & $\begin{array}{l}\text { ed occupations presenting at least } 4 \text { hearths, one floor level and a possible post hole and is dated } \\
\text { microlithic industry, but no pottery and no domestic plant or animal remains. } \\
\text { s.u. } 1003-2,1003 \text { Hearth, } 1003 \text { Under Hearth, 1003-3, 1003-4, 1003-5, 1003-6, 1003-7, } \\
\text { 1004, 1005, 1019, 1006-1, 1006-2, } 1006 \text { Hearth, } 1006 \text { Pit, 1006-3, } 1006 \text { Ash, 1006-4, } 1007 \\
\text { Interfacies, } 1006 \text { Basis }\end{array}$ & $\begin{array}{l}\text { ween } 10,900 \text { and } 6200 \\
\text { s.u. } 1208,1209-1 \text {, } \\
\text { 1209-2, 1209-3 }\end{array}$ \\
\hline Paleolithic & 6 & & $\begin{array}{l}\text { Long phase that spans from the Middle Pleistocene to the Upper Palaeolithic subdivided into } 2 \\
\text { periods (s.u. 1024, 1025). Evident frequentation with bone remains and lithic artefacts }\end{array}$ & \\
\hline
\end{tabular}


Table 3

Khil: summary of the samples analysed and the results of the analysis.

\begin{tabular}{|c|c|c|c|c|c|c|c|c|c|c|c|c|c|}
\hline \multirow[b]{2}{*}{ Period } & \multirow[b]{2}{*}{ Sample } & \multicolumn{2}{|c|}{ Concentration } & \multicolumn{2}{|c|}{ Morphotypes n. } & \multicolumn{2}{|c|}{ Inflorescence } & \multicolumn{2}{|c|}{ Leaf/culm } & \multicolumn{2}{|c|}{ Woody taxa } & \multicolumn{2}{|l|}{ Palms } \\
\hline & & Value & mean & Value & mean & Value & mean & Value & mean & Value & mean & Value & mean \\
\hline \multirow[t]{4}{*}{ Post Neolithic } & EKH-C-8 & 819,799 & 568,508 & 14 & 11 & 42 & 31.5 & 28 & 17 & 5 & 6.5 & 3 & 6.75 \\
\hline & EKH-C-9 & $1,174,836$ & & 9 & & 57 & & 18 & & 4 & & 14 & \\
\hline & EKH-C-10 & 275,039 & & 11 & & 26 & & 6 & & 8 & & 8 & \\
\hline & EKH-C-11 & 4,359 & & 10 & & 1 & & 16 & & 9 & & 2 & \\
\hline \multirow[t]{7}{*}{ Middle Neolithic } & EKH-C-12 & 542 & 115,463 & 2 & 9 & 0 & 10.6 & 1 & 40.6 & 0 & 6.6 & 0 & 38.6 \\
\hline & EKH-C-13 & 1,561 & & 2 & & 0 & & 4 & & 2 & & 0 & \\
\hline & EKH-C-13/2 & 2,101 & & 4 & & 0 & & 3 & & 7 & & 0 & \\
\hline & EKH-B-2005 & 322,565 & & 15 & & 6 & & 100 & & 18 & & 165 & \\
\hline & EKH-C-14 & 37,050 & & 8 & & 0 & & 3 & & 2 & & 5 & \\
\hline & ЕКH-B-2006 & 201,985 & & 17 & & 22 & & 112 & & 9 & & 22 & \\
\hline & EКH-B-2008 & 242,436 & & 15 & & 46 & & 61 & & 8 & & 78 & \\
\hline Early Neolithic B & ЕКH-B-2009 & $1,084,783$ & & 13 & & 97 & & 51 & & 4 & 0 & 29 & 29 \\
\hline \multirow[t]{4}{*}{ Early Neolithic A } & EKH-C-15/2-3 & 16,881 & 7,215 & 7 & 6.75 & 0 & 0.75 & 9 & 0.75 & 0 & 0.5 & 5 & 3.5 \\
\hline & EKH-C-15/3 & 2,624 & & 8 & & 2 & & 8 & & 0 & & 3 & \\
\hline & EKH-C-17 & 1,661 & & 6 & & 0 & & 4 & & 2 & & 0 & \\
\hline & EKH-C-18 & 7,694 & & 6 & & 1 & & 1 & & 0 & & 6 & \\
\hline
\end{tabular}

Table 4

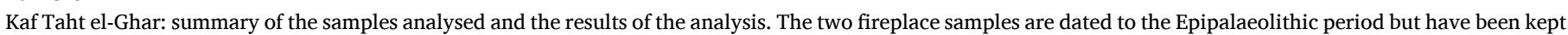

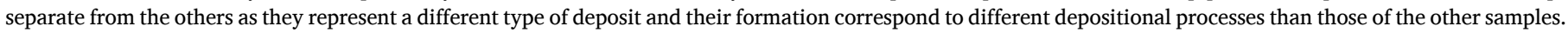

\begin{tabular}{|c|c|c|c|c|c|c|c|c|c|c|c|c|c|}
\hline \multirow[b]{2}{*}{ Period } & \multirow[b]{2}{*}{ Sample } & \multicolumn{2}{|c|}{ Concentration } & \multicolumn{2}{|c|}{ Morphotypes n. } & \multicolumn{2}{|c|}{ Inflorescence } & \multicolumn{2}{|c|}{ Leaf/culm } & \multicolumn{2}{|c|}{ Woody taxa } & \multicolumn{2}{|l|}{ Palms } \\
\hline & & Value & mean & Value & mean & Value & mean & Value & mean & Value & mean & Value & mean \\
\hline Historic & KTG 1.12 & $2,416,331$ & & 11 & & 7 & & 36 & & 12 & & 13 & \\
\hline \multirow[t]{2}{*}{ Middle Neolithic } & KTG 1.10 & 589,063 & 713,566 & 11 & 11 & 3 & 2 & 11 & 10 & 4 & 13.5 & 30 & 21 \\
\hline & KTG 1.8 & 838,068 & & 11 & & 1 & & 9 & & 23 & & 12 & \\
\hline \multirow[t]{3}{*}{ Early Neolithic B } & KTG 1.6 & 505,049 & 482,145 & 8 & 10.7 & 0 & 1 & 10 & 11.7 & 37 & 21.7 & 15 & 14 \\
\hline & KTG 1.3 & 445,668 & & 12 & & 1 & & 9 & & 20 & & 1 & \\
\hline & KTG 2.9 & 495,179 & & 12 & & 2 & & 16 & & 8 & & 26 & \\
\hline \multirow[t]{3}{*}{ Early Neolithic A } & KTG 2.7 & 33,483 & 421,636 & 8 & 6.3 & 0 & 0 & 6 & 6 & 12 & 5 & 27 & 40 \\
\hline & KTG 2.5 & 59,128 & & 5 & & 0 & & 2 & & 2 & & 3 & \\
\hline & KTG 3.16 & $1,172,298$ & & 6 & & 0 & & 10 & & 1 & & 90 & \\
\hline Transition & KTG 2.2 & 946,340 & & 4 & & 0 & & 12 & & 0 & & 178 & \\
\hline \multirow[t]{2}{*}{ Epipalaeolithic } & KTG 3.12 & $1,659,625$ & $7,034,134$ & 9 & 9 & 0 & 1 & 11 & 11.5 & 4 & 5.5 & 364 & 297.5 \\
\hline & KTG 3.10 & $12,408,643$ & & 9 & & 2 & & 12 & & 7 & & 231 & \\
\hline \multirow[t]{2}{*}{ Palaeolithic } & KTG 3.4 & 5,386 & 5,451 & 2 & 1.5 & 0 & 0 & 0 & 0 & 0 & 0 & 0 & 2 \\
\hline & KTG 3.2 & 5,561 & & 1 & & 0 & & 0 & & 0 & & 4 & \\
\hline \multirow[t]{2}{*}{ Fireplaces(Epipaleolithic) } & KTG 3.x & $7,690,415$ & $14,283,901$ & 11 & 10 & 0 & 0 & 12 & 10 & 8 & 5 & 269 & 288 \\
\hline & KTG 3.xx & $20,877,386$ & & 9 & & 0 & & 8 & & 2 & & 307 & \\
\hline
\end{tabular}

and naming follows ICPN 1.0 (Madella et al., 2005)

\section{Results}

\subsection{Phytolith taphonomy}

\subsubsection{Khil}

The phytolith assemblages from Khil generally presents a low level of taphonomic damage. Indeed, the number of elongated cells identified is quite high (Fig. 3) thus advocating for a generally good preservation rate (Madella and Lancelotti, 2012). Some evident signs of pitting, typical of chemical erosion, and mechanical stress have been observed on the phytoliths during analysis, both on elongated as well as on more resistant morphotypes like bulliforms and trichomes (Fig. 4). Taphonomic processes seem to have had a stronger effect on the assemblages of the later periods in samples from grotte $\mathrm{C}$, while no evident sign of damage has been observed on phytoliths from grotte $\mathrm{B}$ or the earlier periods of grotte $\mathrm{C}$.

Average values of phytolith indicators are generally higher for grotte B than grotte C: phytolith concentration (463 k/195 k); number of morphotypes (15/7); inflorescence morphotypes (43/11); leaf/culm morphotypes (81/8.5); woody morphotypes (9.75/3.25); palm morphotypes (73.5/3.8). The relationship between the concentration of phytolith per gram of AIF and number of morphotypes identified in the assemblage shows a low degree of correlation (Fig. 5). This indicates that post-depositional taphonomic processes do not affect the richness of the phytolith assemblages in a significant way (Madella and Lancelotti, 2012).

\subsubsection{Kaf Taht el -Ghar}

The phytolith assemblages observed in Kaf Taht el Ghar show a higher rate of damage due to post-depositional processes. As summarised in Fig. 6, short cells are definitely predominant in the assemblages, while elongated forms are rather scarce and silica skeletons almost absent. However, the assemblages show quite a high number of morphotypes and there is no direct correlation between the phytolith concentration and the number of morphotypes identified in the samples (Fig. 7). Silica skeletons are present mostly in the Epipaleolithic samples, both in the general sediments and in the two fireplaces.

\subsection{Phytolith concentration and morphology}

\subsubsection{Khil}

The assemblages at Khil are characterised by a marked difference between grotte $\mathrm{B}$ and grotte $\mathrm{C}$ both in terms of phytolith concentration and morphology. The sediments collected in grotte $\mathrm{B}$ are much richer in phytolith content as well as in number of morphotypes identified (Table 3). Indeed, grotte B shows an average number of morphotypes that doubles that of grotte $\mathrm{C}$. There is a generalized increase in plant diversity starting from the end of the Early Neolithic period and through 


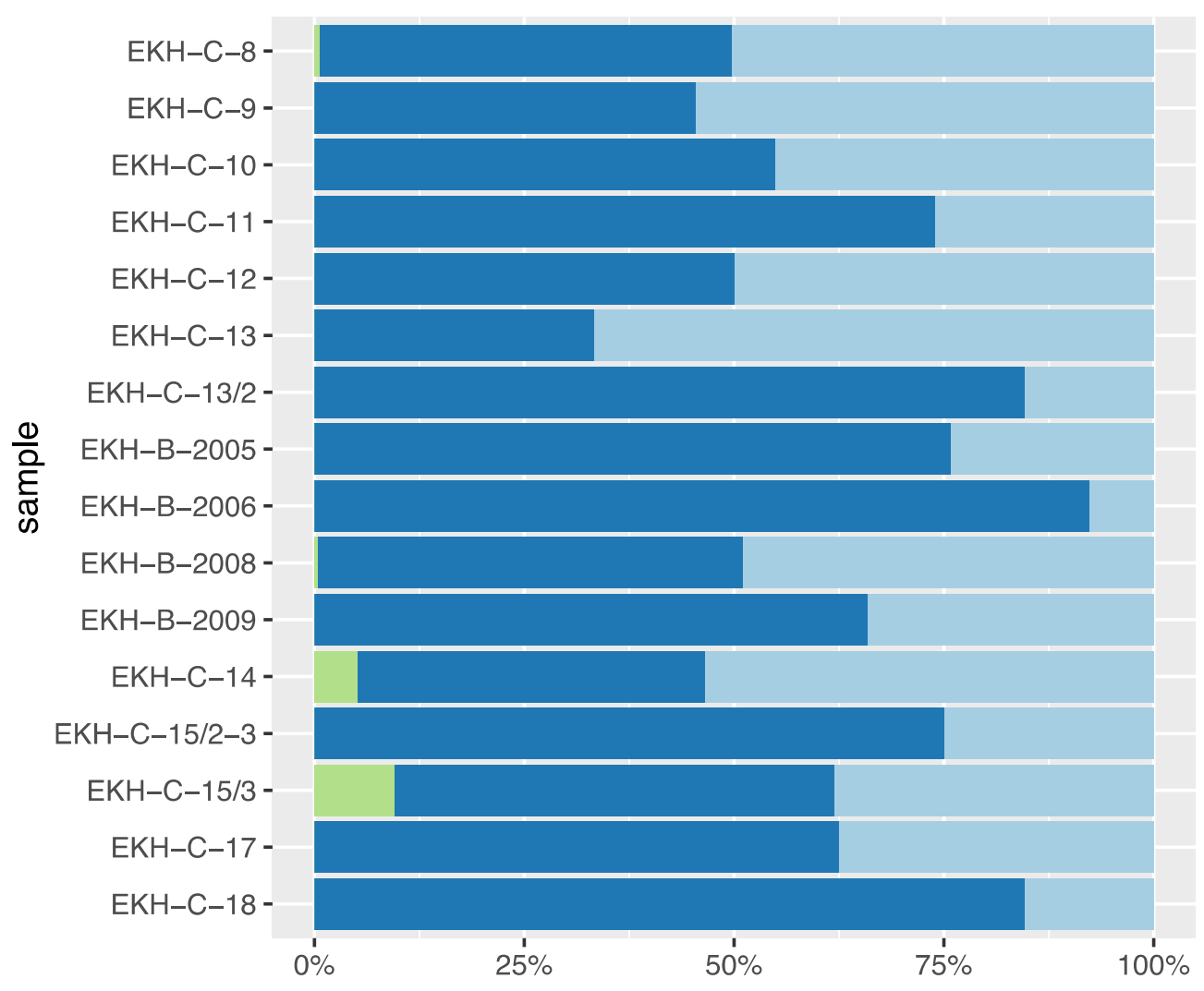

elongate_cells short_cells $\quad$ silica_skeletons

Fig. 3. Khil: proportion of elongate cells, short cells and silica skeletons identified in the samples.

all the Middle Neolithic Period (Fig. 8). This increase is mainly due to the assemblages of grotte $\mathrm{B}$, whereas in grotte $\mathrm{C}$ there seems to be very little activity related to plants until much later, during the Roman frequentation of the cave.

Sample EKH-B-2009, from grotte B, is particularly noticeable as it shows an overall concentration that is as high as the deposits of historic period of grotte $C$ and it presents an amount of inflorescence indicators (elongate echinates and dendritics) that is highest among the samples studied. In addition, the silica skeletons of inflorescence are clearly of two different types indicating the presence of both C3 (wheat and barley type) and C4 (millet type) species. The presence of both C3 and C4 plants at the site is reflected also in the short cells assemblages (Fig. 9). The subfamily Pooideae is by far the most represented however, chloridoids and panicoids are present, especially in the assemblages of grotte B. It is interesting to note the presence of exclusively panicoid type short cells in the assemblage of EKH-C-18, although the absolute amount is rather low, and the evidence is not statistically significant due to the scarcity of phytoliths observed in this sample $(n=14)$. No panicoid short cells were observed in sample EKH-B-2009. However, in this same sample, silica skeletons of C4 inflorescence were observed thus indicating that this group of plants was collected since the earlier occupation of grotte B. Silica skeletons were in general scarce in the assemblages studied (Fig. 3), with the notable exceptions of samples EKH-C-15/3 and EKH-B2009. Both contain silica skeletons of grasses' inflorescence and leaf/ culms, much more abundant in the sample coming from grotte B than in the one coming from grotte $\mathrm{C}$.

\subsubsection{Kaf Taht el-Ghar}

Phytolith concentration per gram of AIF is in general quite low in the sediments of Kaf Taht el-Ghar (Table 4). The two samples from fireplaces have double the concentration of the Epipalaeolithic general samples, which present the highest concentration among the occupation levels. If fireplaces are considered, only these and the Epipalaeolithic samples show a concentration above the mean. When the mean is calculated excluding the fireplaces, only two occupational moments show a concentration above the mean: Epipalaeolithic and Historic times. This is not per se an indication of taphonomy, but it suggests that plants were not commonly used inside the cave.

A total of 19 different morphotypes have been observed in the samples from Kaf That el Gar. In general, and excluding the two fireplaces, the number of morphotypes tends to increase in the most recent samples. Indeed, from a mean of 1.5 in the Palaeolithic levels the number increases to 11 in the Middle Neolithic and Historic levels. The notable exceptions are again the Epipalaeolithic samples: the two fireplaces with a mean of 10 and the general occupations with 9 morphotypes (Table 4).

The most abundant morphotype observed by far in all sample is the globular echinate produced by the leaves of Arecaceae family (palms Fig. 10b-d-e-g-h-). In Fig. 11 these are represented on a scale 100 times higher than for all other morphotypes and are particularly abundant in the Epipalaeolithic fireplaces and in the earlier Neolithic levels. There is seemingly a decrease in the presence of palm phytoliths as time progresses, up to the historic levels where they are very scarce. At the same time,woody indicators (globular psilate, globular granulate, scalloped, sclereids, parallelepipedal and irregular forms), although less represented in absolute terms, seem to follow exactly an opposite trend. Their number starts to increase more or less when palms indicators start to decrease. 

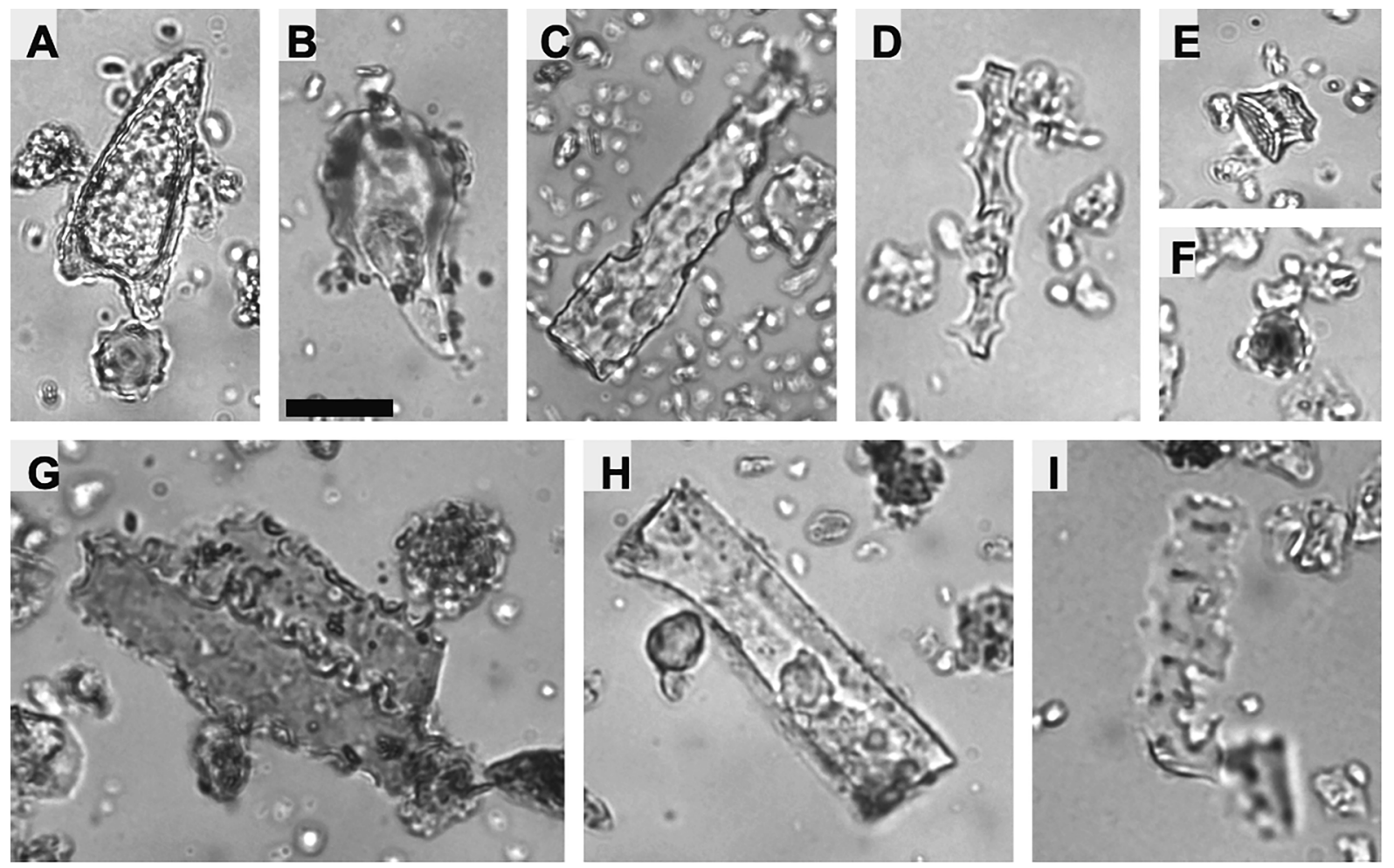

Fig. 4. Khil: microphotographs of significant phytoliths morphotypes. A) globular echinate and trichome; B) Trichome; C) Elongate psilate; D) Elongate echinate; E) Wavy -top rondel; F) Globular echinate; G) Silica skeleton (2 cells) of elongate echinate cells; H) Elongate not determined; I) Elongate (possible echinate). All the phytoliths in this figure (except the globular echinates in A and F and the rondel in E) showing signs of chemical weathering. Scalebar in B $=20 \mu \mathrm{m}$ (valid for all photogrpahs).

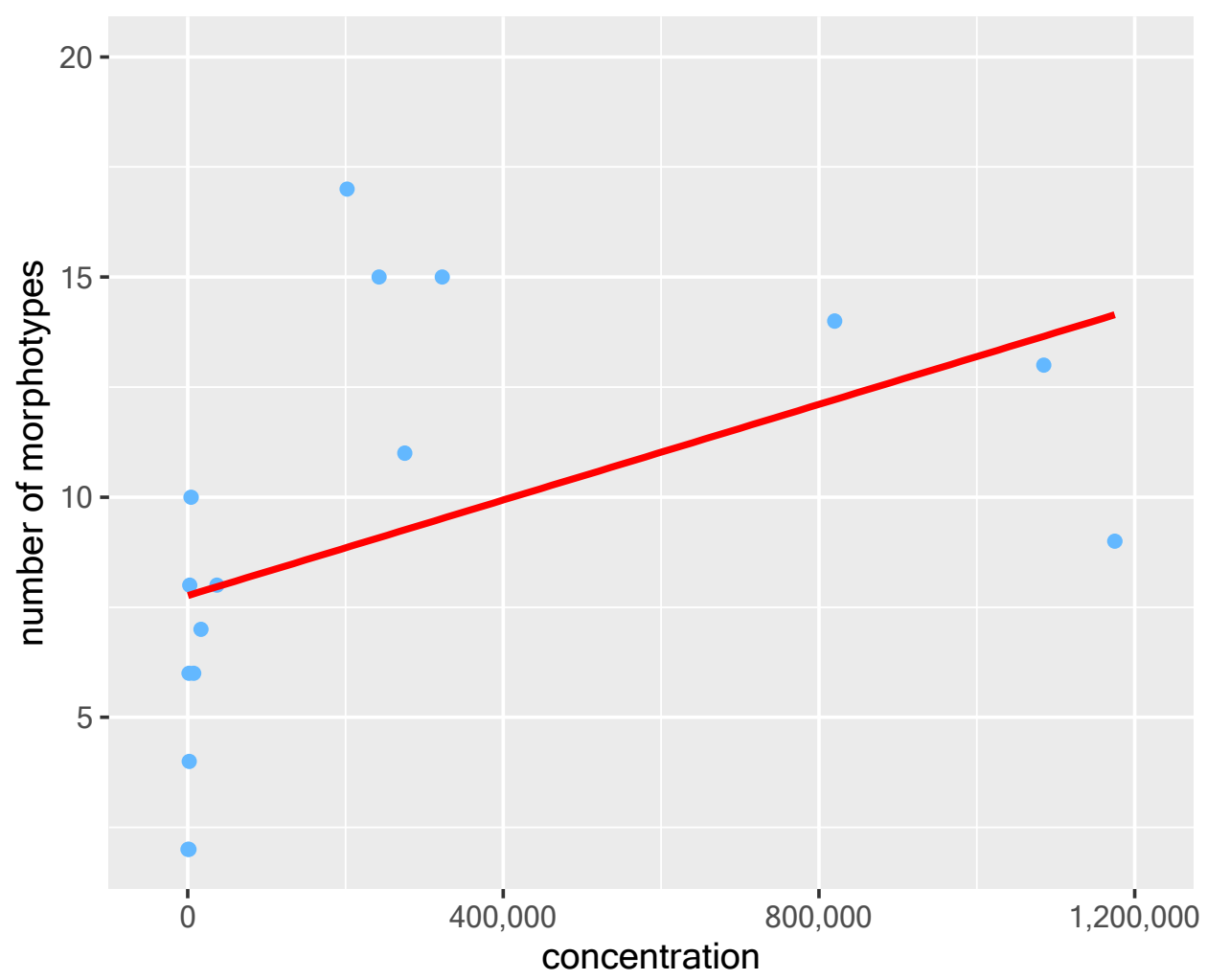

Fig. 5. Khil: correlation between the number of morphotypes identified during analysis (y axis) and the phytolith concentration per gram of AIF (x axis). 


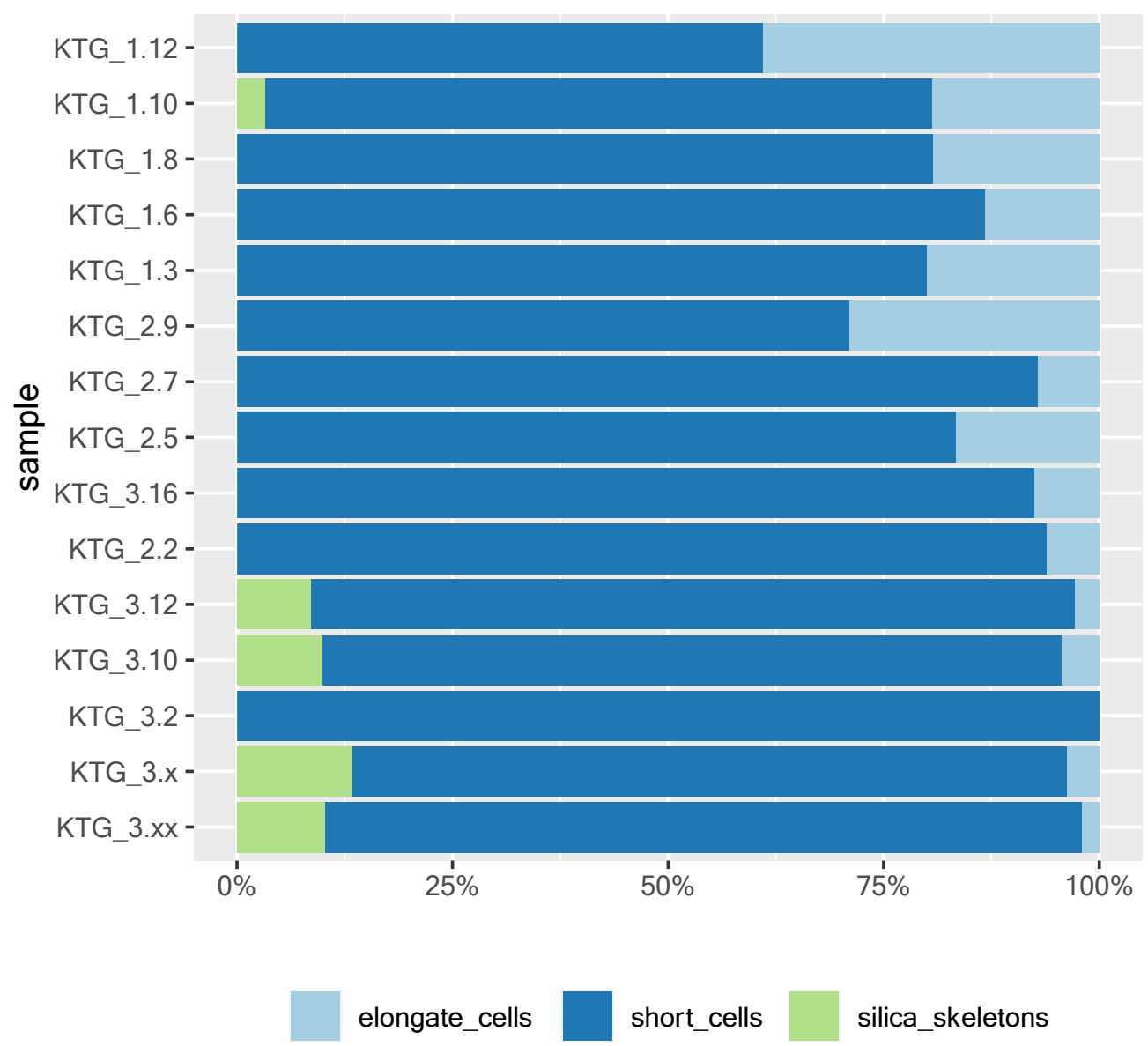

Fig. 6. Kaf Taht el-Ghar: proportion of elongate cells, short cells and silica skeletons identified in the samples.

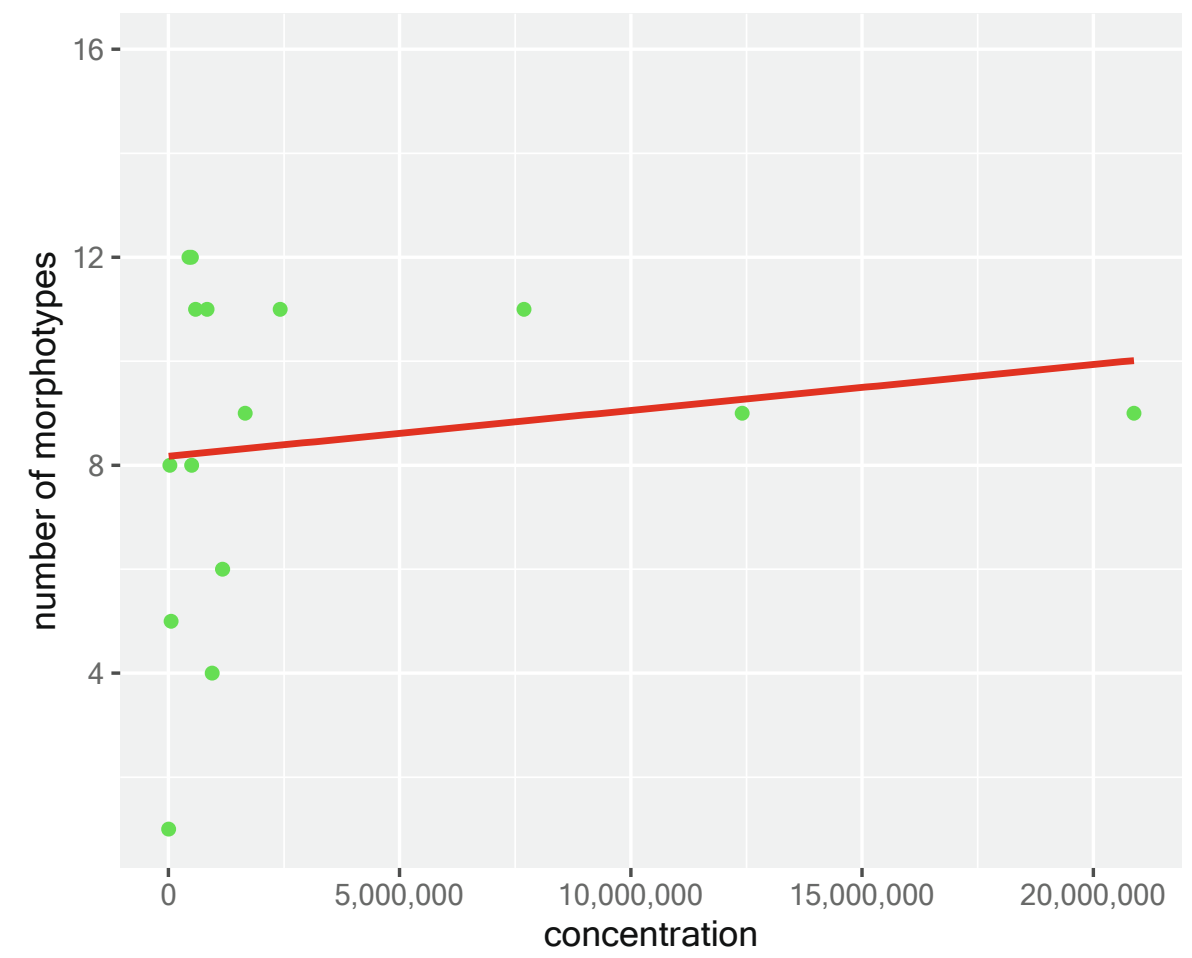

Fig. 7. Kaf Taht el-Ghar: correlation between the number of morphotypes identified during analysis ( $\mathrm{y}$ axis) and the phytolith concentration per gram of AIF ( $\mathrm{x}$ axis). 

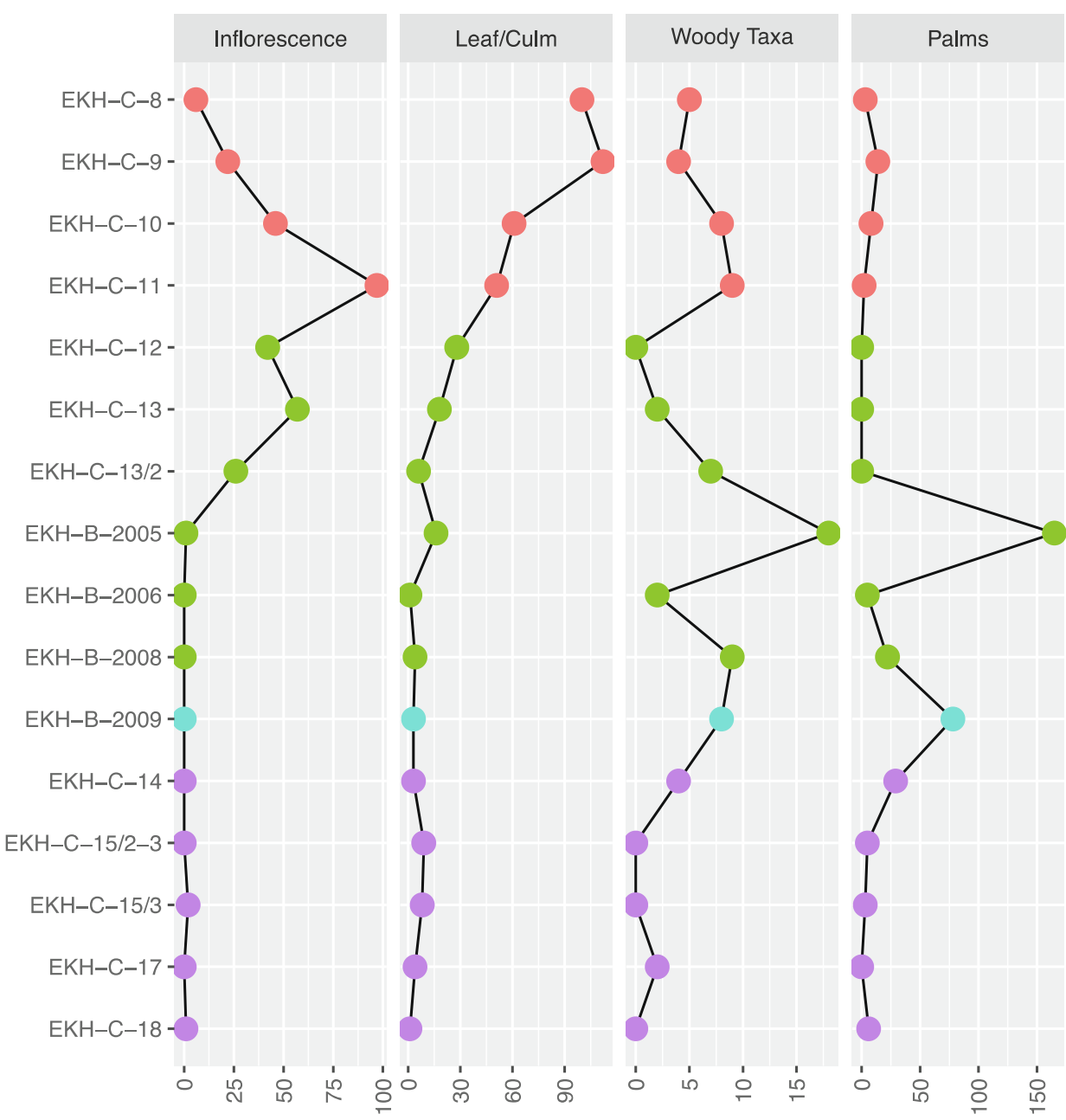

Period

Post-Neolithic

Middle-Neolithic

Early-Neolithic-B

Early-Neolithic-A

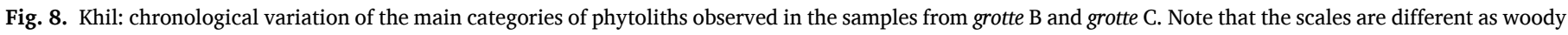
taxa produce fewer phytoliths than the other categories.

Grasses are scarcely present in all the samples analysed and are in general represented by leaf/culm phytoliths (elongate psilate, elongate sinuate and bulliforms). Inflorescence indicators (elongate echinate and dendritics) are very few and practically only present in the upper levels of the Middle Neolithic and Historic periods. In these same levels, leaf/ culm indicators increase as well, following the same trend as phytolith concentration.

Three subfamilies of grasses are represented in the samples, Pooideae, Chloridoideae and Panicoideae (Fig. 12) although Pooideae are predominant. Again, the highest variability is found in the fireplaces and in the Historic period samples. Interesting to note the presence of Panicoideae morphotypes (in this case two bilobates) in sample KTG 1.3 as they are the only encountered in all samples. However, the number of these morphotypes is so small that they are not statistically significant.

\section{Discussion}

\subsection{Evidence of cereal processing and use}

The results of phytolith analysis complement the information offered by charred macro-remains and add some interesting insights on the use of plant resources, as well as the general environmental trends in the Tingitana peninsula of Morocco during the Holocene. Especially at Khil, the general concentration of phytoliths, and the high number of morphotypes encountered, indicate that plant-related activities were definitely taking place inside grotte B. Morales et al., (2016) reports only a few macrobotanical remains from this deposit, the majority of the evidence at Khil being represented by two concentrations of broad beans recovered from grotte $\mathrm{C}$, possibly the result of one episode of accidental burning. The concentration and diversity of phytoliths recovered from grotte $\mathrm{B}$ indicate, in accordance with the presence and abundance of cultural material recovered during excavation (Martínez-Sánchez et al., 2018a), that this cave was occupied more intensely than grotte C; in addition, it suggests that plant-related activities took place preferentially in this location. The high amount of both inflorescence and leaf/ culm morphotypes shows that entire plants were brought into the cave. It is possible that plants were then processed on site to separate the leaves and culms from the edible parts but both components seem to have been used intensively at this location. Leaf/and culms could have been employed as bedding material or fodder for the animals while people consumed the grains. It cannot be excluded that phytoliths could have also entered the archaeological record via the deposition of animal dung. Rests of animal dung have been identified in contemporaneous archaeological sites in the region (Carrión Marco et al., 2018). However, the combined results of macrobotanical and microbotanical analyses, together with the characteristics of the phytolith assemblages, suggests that the observed phytoliths mostly arise from an important use of plants at the site.

The few silica skeletons encountered in the sediments of grotte B advocates for the exploitation of two different groups of grasses were exploited during the Neolithic period at El Khil: C3 types, such as wheat/ barley and C4 types, such as millets (a group that includes wild and cultivated types). Studies have been published with guidelines to identify C3 cerals (e.g., Ball et al., 1999; Portillo et al., 2006) and millets (e. 


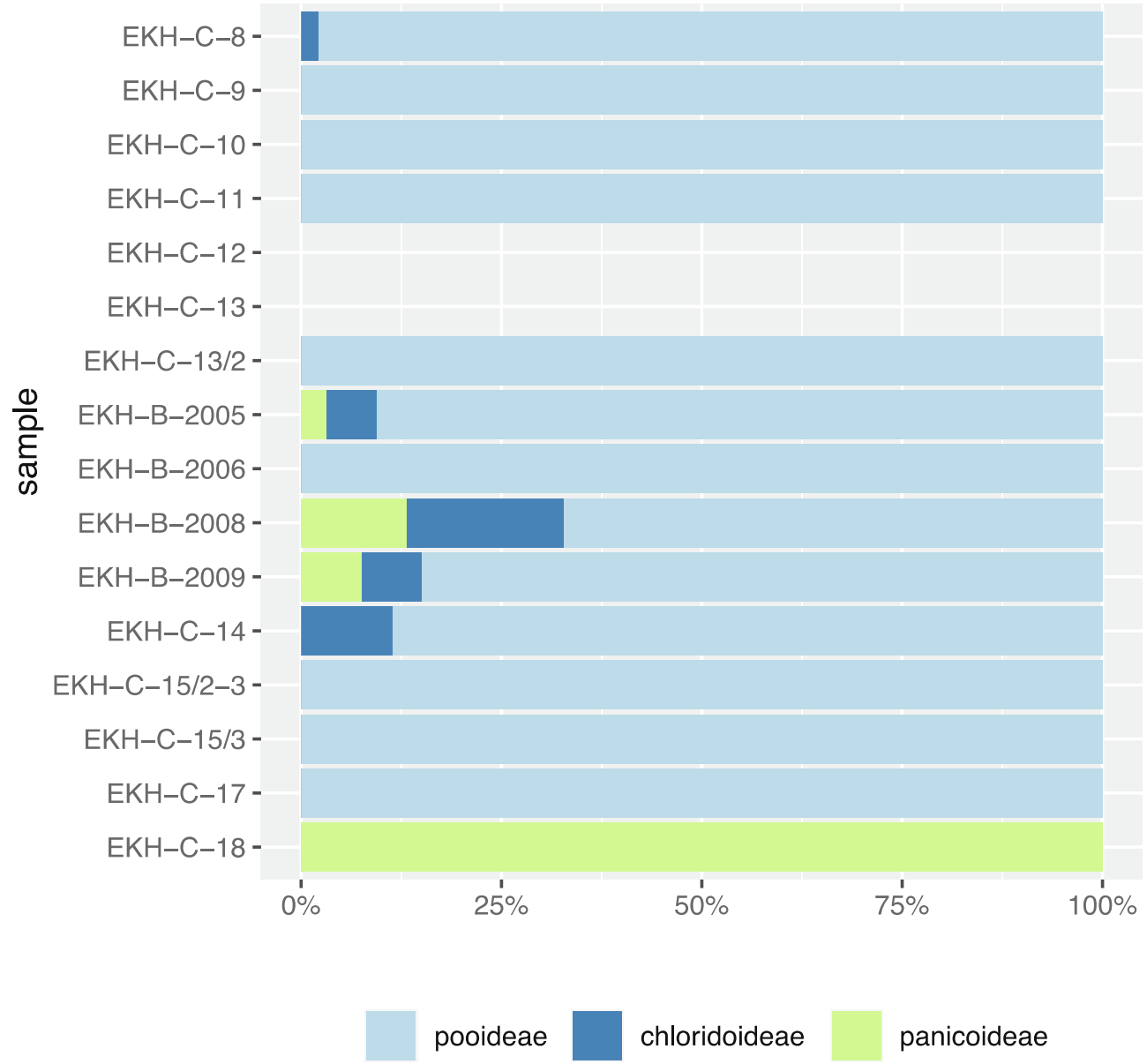

Fig. 9. Khil: chronological variation of the grass subfamilies identified at the site.
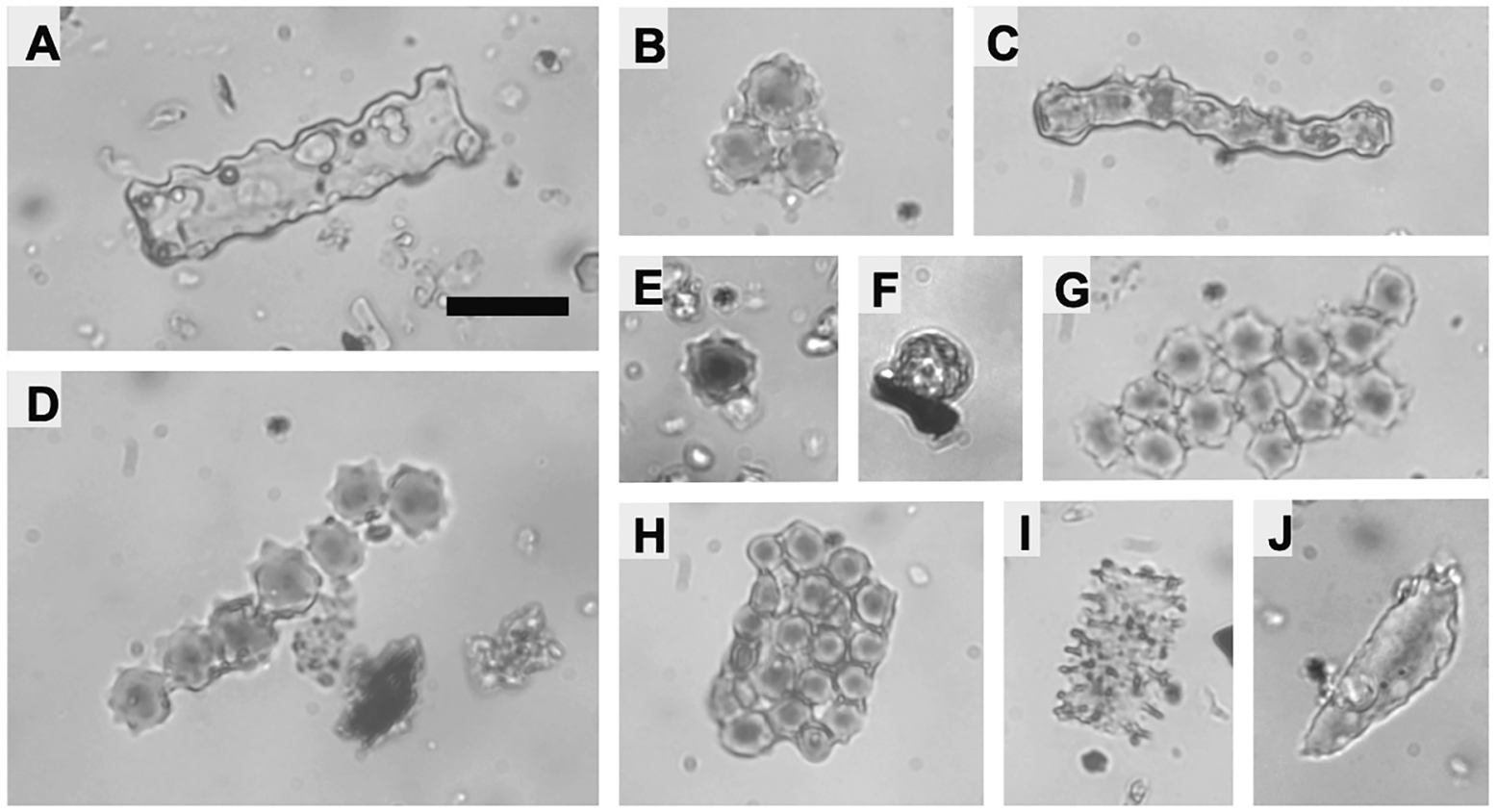

Fig. 10. Kaf Taht el-Ghar: microphotographs of meaningful morphotypes. A) Elongate sinuate with signs of chemical dissolution; B) Silica skeleton of 3 globular echinates; C) Semi-melted long line of globular echinates in anatomical connection; D) Line of globular echinates in anatomical connection; E) Single cell globular echinate; F) Globular granulate; G) Several globular echinates in anatomical connection; H) Silica skeleton of globular echinates; I) Dendriform; J) Trichome with signs of chemical dissolution. Scalebar in $\mathrm{A}=20 \mu \mathrm{m}$ (valid for all photographs). 


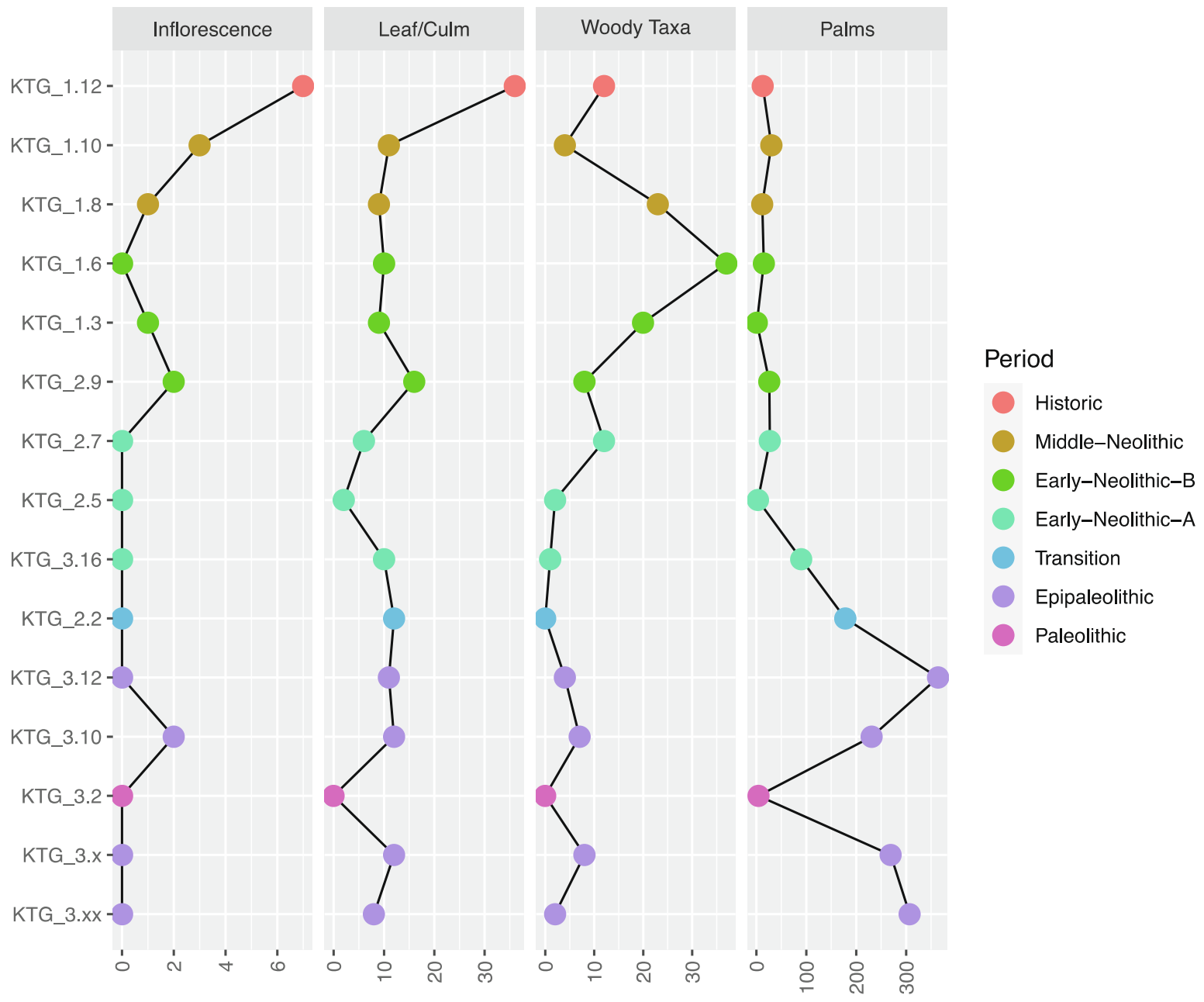

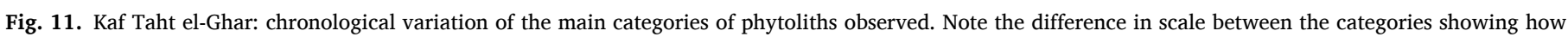

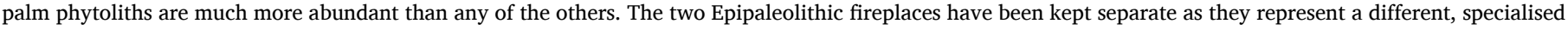
context. However, it is evident their values are in line with those of the other Epipaleolithic samples.

g., Lu et al., 2009, Madella et al., 2016) on the basis of morphometric of elongate inflorescence phytoliths. Unfortunately, the number of cells per each silica skeleton, as well as the quality of preservation, did not allow performing morphometric analysis in order to distinguish the exact genus and/orspecies. However, short cell phytoliths confirm the importance at Khil grotte $\mathrm{B}$ of both groups and grasses are represented by three subfamilies:

1. Pooideae, which includes the main C3 cereals, high elevation grasses and lawn and pastures. This subfamily is identified in the assemblages by short trapeziforms, trapeziform sinuate, trapeziform polylobate and rondels.

2. Chloridoideae, which embodies the majority of draught-adapted short grasses. These include some of the common weeds of cultivated fields in the dry tropics (Piperno, 2006, 28) as well as some of the edible "millets" (Madella et al., 2016). This subfamily is represented in the assemblage by elongate trapeziforms and saddle. Saddles are occasionally produced by other non-chloridoideae taxa, however these are normally classified as "tall" saddles (Neumann et al., 2019; Supplementary data File 1), which have not been identified during this study. Panicoideae, which are tall grasses of tropical origins and includes all the main millet type cereals (Madella et al., 2016) and many wild species. This subfamily is represented in the assemblage by bilobates. This morphotype, in its broad definition, can be produced by species in other subfamilies, specifically certain pooid grasses in the Tribe Stipae (a wild grass that could have been present near the site). However, Stipae bilobates are quite characteristic, with poorly separate lobes and trapezoidal longitudinal sections (Neumann et al., 2019; Supplementary data File 1), and such morphotypes have not been observed in the samples analysed.

Interestingly, the results of the study of macrobotanical remains showed no presence of C4 plants (Morales et al., 2016). This discrepancy between the absence of grains from C4 plants and the indication of their presence and consumption highlighted by alternative proxies (phytolith, starch, stable isotopes, etc), has been noted in several other contexts (see for example Delhon et al., 2020, Sureda et al., 2017). This discrepancy could be explained by differential preservation and recovery rates in the macrobotanical record whereby grains of C3 species, which are usually bigger than those of $\mathrm{C} 4$, have more chances to be part of the macrobotanical assemblages. A possible alternative, in the present case, is that C4 grasses were not collected for consumption.

At both sites the silica skeletons of grass taxa with edible grains do not display the neat transversal or curved fractures that have been associated with the process of threshing (Anderson et al., 2004). However, in light of the macrobotanical evidence, most probably belong to cultivated/domesticated crops since the earlier Neolithic deposits at Khil grotte $\mathrm{B}$. In contrast, grotte $\mathrm{C}$ does not seem to be an important location for plant-related activities until up to the Historic periods. In fact, it is notable that grotte $\mathrm{C}$ displays a very low amount of phytoliths during the entire Neolithic sequence, even in s.u. 12 and 13 that, 


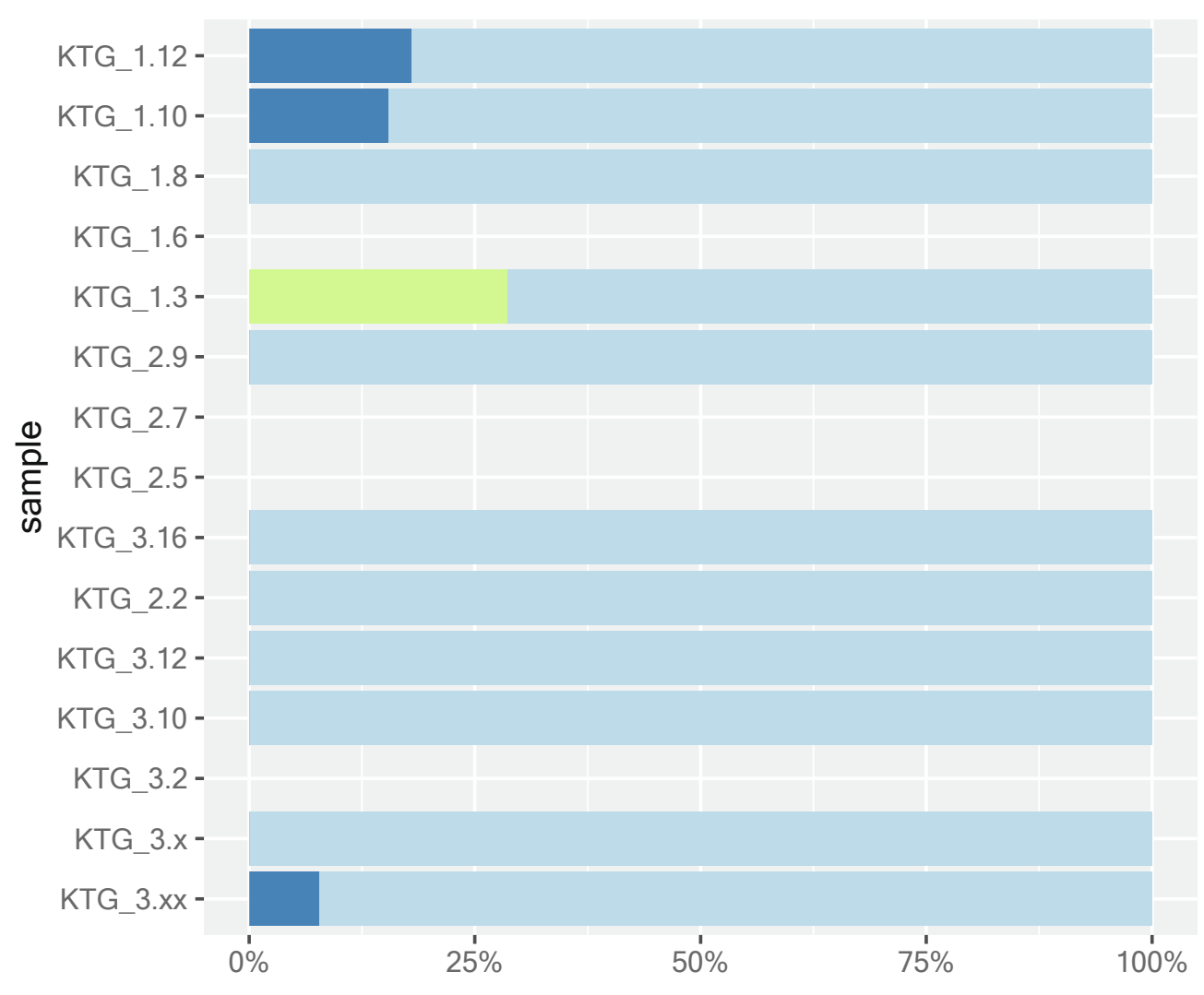

pooideae chloridoideae panicoideae

Fig. 12. Kaf Taht el -Ghar: chronological variation of the grass subfamilies identified at the site of Kaf That el Gar.

according to the excavation report, represent frequent occupation episodes. On the contrary, s.u. 8 and 10, which represent periods of abandonment, show a discrete amount of phytoliths both of leaf/culm and inflorescence. Also interesting to notice is the amount of woody taxa indicators observed in the upper layers of grotte $\mathrm{C}$. These concentrations could probably represent enrichment due to intense bioturbation, with phytoliths percolating from the layers above. The deposit of grotte $\mathrm{C}$ in general, and especially the upper levels, seem more affected by postdepositional taphonomic processes and this might be the reason for the scarcity of phytoliths observed in these samples.

Carpological analysis conducted by Ballouche and Marinval (2003) and Morales and colleagues (2016) detected the presence of domesticated wheat on site. Phytolith analysis, however, indicates that little or no activity related to crop processing was taking place at Kaf Taht elGhar during the time of occupation. The scarcity of inflorescence morphotypes might be caused by post-depositional diagenetic processes. As shown in Fig. 6 elongated cell phytoliths are less than $40 \%$ in the richest sample (historic period) and they are lower than $30 \%$ in the richest Neolithic level. The predominance of short cells over elongated forms and the absence of silica skeletons might indicate a high rate of phytolith post depositional damage (Madella and Lancelotti, 2012). Indeed, elongated cells are usually less silicified than short cells and generally more likely to be affected by chemical taphonomic processes, especially the morphotypes produced in the floral part of the plants (Cabanes et al., 2011; Cabanes and Shahack-Gross, 2015). However, as shown by Fig. 7 , there is no correlation between phytolith concentration and the number of morphotypes identified, thus suggesting that the taphonomic processes -however present- did not seriously affect the richness of the assemblages (Madella and Lancelotti, 2012). If the scarcity of inflorescence morphotypes is not to be attributed to taphonomy, it is most probable that second stages of crop processing were taking place outside the cave or in other locations and grains were introduced clean after processing. On the contrary the presence in the assemblages of leaf and culm indicators, although not abundant, might imply that either the first stages of crop processing were happening inside or that some byproducts of threshing were indeed collected and transported inside the cave. Leaves and culms could have been used as fodder for animals, as bedding or matting material as well as for fuel. Grasses are represented at Kaf Taht el-Ghar by three subfamilies: Pooideae, Chloridoideae and Panicoideae. However, C3 pooids grasses are by far the most representative group of grasses identified in the phytolith assemblages, they are well adapted to cool and wet climates and include the most common Near Eastern cereals, such as wheat and barley (Piperno, 2006). Unfortunately, no silica skeleton of this group has been observed in the samples, which makes it impossible to determine whether the pooid plants that were used at the site belong to such genera. Also, it is impossible to say whether they are the remains of wild or domesticated species. The other two subfamilies are scarcely represented indicating that, if used, they did not constitute an important resource.

\subsection{The presence and use of palm leaves}

Throughout the sequence the amount of Arecaceae indicators is quite high both at Khil and at Kaf Taht el-Ghar. These are represented by globular echinate forms, which are produced by the leaves of palms. A few studies have used statistic applications of measurements of size and shape to globular echinates in order to discriminate between different species of palms (Albert et al., 2009, Fenwick et al., 2011). During this 
study, measurements could not be performed as most phytoliths showed signs of burning and/or heat alterations (Fig. 10-c). However, the most common species of Arecaceae in the Mediterranean are Chamaerops humilis (dwarf palm), Phoenix sylvestris and Phoenix dactylifera. No palm remains were identified in the macrobotanical record at Khil and only one seed of Chamaerops humilis was recovered from Kaf Taht el-Ghar (Morales et al., 2016). However, the dwarf palm is very common along the Mediterranean littoral and palm are attested in the eastern part of Maghreb where several seeds have been identified in the Neolithic levels at Ifri Oudadane (Morales et al., 2016) and phytoliths from Arecaceae have been found in fireplaces at Ifri n'Amr ou Moussa (Carrión Marco et al., 2018) and in the early sequence of Ifri el Baroud (Potí et al., 2019).

Apart from the consumption of the fruits of date palm, the leaves of all three species could be used for different scopes in African rural communities such as huts (Scarin, 1937; Despois, 1946; Baroin and Pret, 1993) matting (Tinthoin, 1946), to make beds and other furniture (Dugast, 1940), to embellish ritual masks (Drewal and Drewal, 1982) and to decorate pottery and other containers (Martínez-Sánchez et al., 2018a; Peña-Chocarro et al., 2015). Keepnets and nets for fishing made of palm leaves are reported to have been in use until very recent times along the Tunisian coast (Romdhane, 1998). Although it is not possible to state exactly what these palm leaves were used for, it seems they were present at Khil in both grotte $\mathrm{B}$ and grotte $\mathrm{C}$ during the entire sequence although they tend to decrease in time. This might be an indication of a climatic and/or environmental change or it might indicate a decrease in intensity of use of these resources. At Kaf Taht el-Ghar palm leaves seemed to have been a very important resource during the Epipaleolithic. The characteristic globular echinates are the most common morphotype observed in the sediments analysed, present in all samples on a scale that is 100 times higher than any other morphotype. Globular echinates are also very abundant in the two samples from fireplaces indicating that palm leaves were possibly used for fuel or that items made with them were -intentionally or unintentionally- burnt. Indeed, in these samples globular echinates have been observed both as disarticulated and as articulated phytolith (silica skeletons) some of which appeared as an agglutination of several semi-melted particles (Fig. 10). This indicates that the temperature achieved during combustion was quite high as phytoliths start to melt at about $900{ }^{\circ} \mathrm{C}$. These fireplaces might have served some specific purpose (palm leaves seem to produce a "slow" fire but "bright" embers; Plinio translated by Domenichi, 1612) and maybe they were used for some sort of material transformation.

At present, it is difficult to discern whether the use of palm leaves is a choice or it is driven by environmental factors. When the tendency of palm leaves indicators is compared with that of woody taxa indicators, the two present opposite trends and the latter starts increasing only when the former completely disappears (Fig. 11). According to palynological studies of marine cores (Fletcher and Sánchez Goñi, 2009) the beginning of the Epipaleolithic at Kaf That el-Ghar coincides with the beginning of the Younger Dryas, a phase of expansion of the desert. Therefore, it is not surprising to see a high number of palm morphotypes, as palms are better adapted to arid conditions than other woody taxa. However, if the use of palm versus other species was exclusively related to environmental conditions, we should see an increase in woody taxa much earlier than what we observed as the oceanic moist conditions sets in (c. 9700-3400 cal. BC, Fletcher and Sánchez Goñi, 2009), thus suggesting a deliberate selection for the use of palms. The increase in woody taxa at Kaf Taht el-Ghar seems to loosely follow the increase in humid conditions after the end of Younger Dryas and the subsequent onset of arid conditions that are observed both in marine cores and in terrestrial records of the Southeastern Iberian Peninsula (Fletcher and Sánchez Goñi, 2009), albeit with a lag of few millennia. In parallel, pollen analyses from Hahua Fteah seem to point to an increase in the maquis vegetation indicators in the upper levels of the excavation (Facies 1 from Paleolithic to historic times, Inglis et al., 2013) that roughly coincides with the increase in woody taxa morphotypes observed at Kaf
Taht el -Ghar. However, as changes in the vegetations in the study area might be very localised, more terrestrial paleoenvironmental records at local scale are needed to definitely interpret the trends observed in the phytoliths.

\section{Conclusions}

The analysis of phytoliths from grotte $\mathrm{B}$ and grotte $\mathrm{C}$ at the archaeological site of Khil, indicates that this location is particularly important for the study of the beginning of agriculture in North Africa. Especially grotte $\mathrm{B}$ contributes highly to our understanding of the people-plant relationship in this area. From the very beginning of the Early Neolithic sequence there appear evidence of an intense use of plants by the occupants of the cave. The surrounding C3 and C4 vegetation was exploited and C 3 crops were cultivated. At the same time a wide array of other plants is used, such as palms and woody plants. The presence of palms along the entire sequence tends to decrease at the end of the occupation, starting from the end of the Neolithic. Further localised palaeoenvironmental work, with terrestrial proxies is needed to clarify whether this is due to a climatic variation or anthropic choice.

Phytolith analysis at the site of Kaf Taht el-Ghar indicates that crop processing was most probably not taking place on site. However, the predominance of C3 plants in the samples agrees with the finding of previous macro botanical studies that identified cultivated wheat and barley in this cave's deposits. It is most probable that grains were imported and consumed clean after processing was carried out in the vicinity but outside the cave. Indeed, the presence of culm/leaves grasses within the deposits might indicate the preferential transport of these processing by-products to the cave and thereby suggesting that threshing was performed in a location where by-products could then be transported to the site.

An interesting aspect of the phytolith assemblages at both Khil and Kaf Taht el-Ghar is the widespread use of palm leaves and their gradual disappearance through time as they are substituted by woody species. Palm leaves could have been used as fodder, containers, baskets, matting, and fuel or to make small furniture items. There is a high probability that palm leaves were used as fuel at Kaf That el Gar where globular echinates were common in the two fireplaces analysed. However, it might be hypothesised that if palm leaves were heavily exploited the fruit might have also been available for the people to eat. Indeed, macro-remain analysis at Ifri Oudadane showed that date seeds from the dwarf palm were frequent along the entire Neolithic sequence. It is to be supposed therefore that palm dates were probably consumed also at Khil and Kaf Taht el-Ghar where extremely high concentrations of globular echinate were found.

\section{CRediT authorship contribution statement}

Carla Lancelotti: Formal analysis, Investigation, Data curation, Writing - original draft, Writing - review \& editing, Visualization. Rafael M. Martínez Sánchez: Investigation, Resources, Writing - review \& editing, Visualization. Juan Carlos Vera Rodríguez: Investigation, Resources, Writing - review \& editing, Visualization. Guillem PérezJordà: Investigation, Resources, Writing - review \& editing. Leonor Peña-Chocarro: Conceptualization, Resources, Writing - review \& editing, Supervision, Project administration, Funding acquisition. Stefano Biagetti: Investigation, Writing - review \& editing, Visualization. Marco Madella: Methodology, Investigation, Supervision, Writing review \& editing.

\section{Declaration of Competing Interest}

The authors declare that they have no known competing financial interests or personal relationships that could have appeared to influence the work reported in this paper. 


\section{Acknowledgements}

This research was conducted in the framework of the AGRIWESTMED project (ERC-2008-AdG Proposal No 230561). CL, SB and $\mathrm{MM}$ are part of the Culture and Socio-Ecological Dynamics Research Group (2017 SGR-212). The authors want to especially thank the National Institute for Archaeology and Heritage (INSAP) for granting the excavation permits. CL thanks Abel Ruiz-Giralt for help with graphics and R.

\section{Appendix A. Supplementary data}

Supplementary data to this article can be found online at https://doi. org/10.1016/j.jasrep.2021.102921.

\section{References}

Albert, R.M., Weiner, S., 2001. Study of phytoliths in prehistoric ash layers from Kebara and Tabun Caves using a quantitative approach. In: Meunier, J.D., Colin, F. (Eds.), Phytoliths: applications in earth sciences and human history. AA Balkema, Abingdon, pp. 251-266.

Albert, R.M., Bamford, M.K., Cabanes, D., 2009. Palaeoecological significance of palms at Olduvai Gorge, Tanzania, based on phytolith remains. Quat. Int. 193, 41-48.

Anderson, P.C., Chabot, J., van, Gijn A. 2004. The Functional Riddle of 'Glossy' Canaanean Blades and the Near Eastern Threshing Sledge. J. Mediterran. Archaeol. 17(1), 87-130.

Ball, T.B., Gardner, J.S., Anderson, N. 1999. Identifying Inflorescence Phytoliths from Selected Species of Wheat (Triticum monococcum, T. dicoccon, T. dicoccoides, and T. aestivum) and Barley (Hordeum vulgare and H. spontaneum (Gramineae). Am. J. Bot. 86 (11), 1615-1623.

Ballouche, A., Marnival, P., 2003. Données palynologiques et carpologiques su la domestication des plantes et l'agriculture dans le Néolithique ancien dans le Maroc septentrional (site de Kaf Taht el-Ghar). Revue d'Archéométrie 27, 49-54.

Baroin, C., Pret, P-F. 1993. Le palmier du Borkou, végétal social total. Journal des africanistes, 1993, tome 63,fascicule 1, 5-20.

Benjamin, J., Rovere, A., Fontana, A., Furlani, S., Vacchi, M., Inglis, R.H., Galili, E., Antonioli, F., Sivan, D., Miko, S., Mourtzas, N., Felja, I., Meredith-Williams, M., Goodman-Tchernov, B., Kolaiti, E., Anzidei, M., Gehrels, R., 2017. Late Quaternary sea-level changes and early human societies in the central and eastern Mediterranean Basin: An interdisciplinary review. Quat. Int. 449, 29-57. https://doi org/10.1016/j.quaint.2017.06.025.

Broodbank, C., 2013. The Making of the Middle Sea: A History of the Mediterranean from the Beginning to the Emergence of the Classical World. Thames and Hudson, London.

Broodbank, C., Lucarini, G., 2019. The Dynamics of Mediterranean Africa, ca. 9600-1000 bc: An Interpretative Synthesis of Knowns and Unknowns. J. Mediterran. Archaeol. 32 (2), 195-267.

Cabanes, D., Weiner, S., Shahack-Gross, R., 2011. Stability of phytoliths in the archaeological record: a dissolution study of modern and fossil phytoliths. J. Archaeol. Sci. 39 (9), 2480-2490.

Cabanes, D. and Shahack-Gross, R., 2015. Understanding fossil phytolith preservation: the role of partial dissolution in paleoecology and archaeology. PloS One 10(5), p. e0125532.

Carrión Marco, Y., Morales, J., Portillo, M., Pérez-Jordá, G., Peña-Chocarro, L., Zapata, L. 2018. The Use of Wild Plants in the Palaeolithic and Neolithic of Northwestern Africa: Preliminary Results from the PALEOPLANT Project, in: Mercuri, A. M., D'Andrea, A. C., Fornaciari, R., Höhn, A. (Eds.), Plants and People in the African Past. Progress in African Archaeobotany. Springer Nature, Switzerland, pp. 146-174.

Clarke, J., Brooks, N., Banning, E.B., Bar-Matthews, M., Campbell, S., Clare, L., Cremaschi, M., di Lernia, S., Drake, N., Gallinaro, Marina, Manning, S., Nicoll, K., Philip, G., Rosen, S., Schoop, U.-D., Tafuri, M.A., Weninger, B., Zerboni, A., 2016. Climatic changes and social transformations in the Near East and North Africa during the 'long' 4th millennium BC: A comparative study of environmental and archaeological evidence. Quat. Sci. Rev. 136, 96-121. https://doi.org/10.1016/j. quascirev.2015.10.003.

Cremaschi, Mauro, Zerboni, Andrea, Mercuri, Anna Maria, Olmi, Linda, Biagetti, Stefano, di Lernia, Savino, 2014. Takarkori rock shelter (SW Libya): an archive of Holocene climate and environmental changes in the central Sahara. Quat. Sci. Rev. 101, 36-60. https://doi.org/10.1016/j.quascirev.2014.07.004.

Daugas, J.-P., El Idrissi, A., Ballouche, A., Marinval, P., Ouchaou, B., 2008. Le Néolithique ancien au Maroc septentrional. Bulletin de la Société préhistorique française 105 (4), 787-812.

Delhon, Claire, Binder, Didier, Verdin, Pascal, Mazuy, Arnaud, 2020. Phytoliths as a seasonality indicator? The example of the Neolithic site of Pendimoun, south-eastern France. Vegetation History and Archaeobotany 29 (2), 229-240.

DeMenocal, P.B., 2001. Cultural responses to climate change during the late Holocene. Science 292, 667-673.

Despois, J., 1946. Mission scientifique au Fezzân (1944-1945). Géographie humaine, Paris, Lechevalier.

Drewal, H.J., Drewal, M. 1982. Gelede. Art and Female Power among the Yoruba. Bloomington, Indiana University Press.
Dugast, R., 1940. L'habitation chez les Ndiki du Cameroun. Journal de la Société des Africanistes 1940, tome 10, 99-125.

Fletcher, W.J., Sánchez Goñi, M.F., 2009. Orbital-and sub-orbital-scale climate impacts on vegetation of the western Mediterranean basin over the last 48,000 yr. Quat. Res. 70 (3), 451-464.

Fenwick, R.S.H., Lentfer, C.J., Weisler, M.I., 2011. Palm reading: a pilot study to discriminate phytoliths of four Arecaceae (Palmae) taxa. J. Archaeol. Sci. 38, 2190-2199.

Hublin, Jean-Jacques, Ben-Ncer, Abdelouahed, Bailey, Shara E., Freidline, Sarah E., Neubauer, Simon, Skinner, Matthew M., Bergmann, Inga, Le Cabec, Adeline, Benazzi, Stefano, Harvati, Katerina, Gunz, Philipp, 2017. New fossils from Jebel Irhoud, Morocco and the pan-African origin of Homo sapiens. Nature 546 (7657), 289-292. https://doi.org/10.1038/nature22336.

Inglis, R., Farr, L., Hunt, C., Hill, E., Simpson, D., 2013. Environmental Change in the Haua Fteah Sediments. Poster presented at the Conference. Unravelling Human Origins, St John's College, Cambridge.

Kuper, R., Kröpelin, S., 2006. Climate-Controlled Holocene Occupation in the Sahara: Motor of Africa's Evolution. Science 313, 803-807.

Lu, H., Zhang, J., Wu, N., Liu, K.-B., Xu, D., Li, Q. 2009. Phytoliths Analysis for the Discrimination of Foxtail Millet (Setaria italica) and Common Millet (Panicum miliaceum). PLoS ONE 4(2): e4448.

Madella, M., Alexandre, A., Ball, T., 2005. International code for phytolith nomenclature 1.0. Ann. Bot. 96 (2), 253-260.

Madella, M., Lancelotti, C., 2012. Taphonomy and phytoliths: a user manual. Quat. Int. 275, 76-83.

Madella, M., Lancelotti, C., García-Granero, J.J., 2016. Millet microremains-an alternative approach to understand cultivation and use of critical crops in Prehistory. Archaeol. Anthropol. Sci. 8 (1), 17-28.

Madella, M., Power-Jones, A.H., Jones, M.K., 1998. A simple method of extraction of opal phytoliths from sediments using a non-toxic heavy liquid. J. Archaeol. Sci. 25, 801-803.

Martínez-Sánchez, R.M., Vera-Rodríguez, J.C., Peña-Chocarro, L., Bokbot, Y., PérezJordà, G., Pardo-Gordó, S., 2018a. The Middle Neolithic of Morocco's North-Western Atlantic Strip: New Evidence from the El-Khil Caves (Tangier). Afr. Archaeol. Rev. 35, 417-442.

Martínez-Sánchez, R.M., Vera-Rodríguez, J.C., Pérez-Jordà, G., Peña-Chocarro, L., Bokbot, Y. 2018b. The beginning of the Neolithic in northwestern Morocco. Quat. Int. 470, 485-496.

Martínez-Sánchez, R.M., Vera-Rodríguez, J.C., Pérez-Jordà, G., Moreno-García, M Bokbot, Y., Peña-Chocarro, L. 2021. Revisiting the Epipalaeolithic-Neolithic transition in the extreme NW of Africa: The latest results of the chronological sequence of the cave of Kaf Taht el-Ghar (Tétouan, Morocco). Afr. Archaeol. Rev. doi.org/10.1007/s10437-021-09425-x.

Morales, J., Pérez, G., Peña-Chocarro, L., Zapata, L., Ruiz, M., López, J.A., Linstädter, J., 2013. The origins of agriculture in north-west Africa: Macro-botanical remains from Epipalaeolithic and early Neolithic levels of Ifri Oudadane (Morocco). J. Archaeol. Sci. 40, 2659-2669.

Morales, J., Pérez Jordá, G., Peña-Chocarro, L., Bokbot, Y., Vera, J.C., Martínez Sáchez, R.M., Linstadter, J., 2016. The introduction of South-Western Asian domesticated plants in North-Western Africa: An archaeobotanical contribution from Neolithic Morocco, Quat. Int. 412, 96-109.

Neumann, Katarina, Strömberg A.E., Caroline, Ball, Terry, Albert, Rosa Maria, Vrydaghs, Luc, Scott Cummings, Linda, 2019. International Code for Phytolith Nomenclature (ICPN) 2.0. Ann. Botany 124, 189-199. https://doi.org/10.1093/ aob/mcz064.

Peña-Chocarro, L., Pérez Jordá, G., López-Romero, E., Gibaja, J., Rodríguez, A., Iriarte, E., Pardo, S., Vera, J.C., Martínez-Sanchez, R.M. 2012. Informe de la Excavación Hispanomarroquí en las Cuevas de El Khil (Norte de Marruecos), Septiembre 201112-15. Unpublished Report.

Peña-Chocarro, L., Pérez Jordà, G., Morales Mateos, J., Zapata, L., 2015. Storage in traditional farming communities of the western Mediterranean: Ethnographic, historical and archaeological data. Environ. Archaeol. 20 (4), 379-389.

PhytCore Database. https://www.phytcore.org/phytolith/index.php? $\mathrm{rdm}=2 \mathrm{bQpEfbZEO \& action}=$ home. Last accessed, January 2021.

Piperno, D.R. 2006. Phytoliths. A Comprehensive Guide for Archaeologists and Paleoecologists. Lanham, Altamira Press.

Plinio. Historia Naturale di G. Plinio Secondo divisa in trentasette libri. Tradotta per Lodovico Domenichi. Libro Decimoterzo: Delle Palme, natura \& generi loro, pagina 295-298. Giorgio Bizzardo Editore, Venezia, 1612..

Portillo, M., Ball, T., Manwaring, J., 2006. Morphometric analysis of inflorescence phytoliths produced by Avena sativa L. and Avena strigos schreb. Econ. Bot. 60 $121-129$.

Potí, A., Kehl, M., Broich, M., Marco, Y.C., Hutterer, R., Jentke, T., Linstädter, J., LópezSáez, J.A., Mikdad, A., Morales, J., Pérez-Díaz, S., 2019. Human occupation and environmental change in the western Maghreb during the Last Glacial Maximum (LGM) and the Late Glacial. New evidence from the Iberomaurusian site Ifri El Baroud (northeast Morocco). Quat. Sci. Rev. 220, 87-110.

Romdhane, M.S., 1998. La pêche artisanale en Tunisie. Évolution des techniques ancestrales. Mélanges de l'École française de Rome. Antiquité, tome 110 (1), 61-80.

Sahnouni, M., Parés, J.M., Duval, M., et al., 2018. 1.9-million- and 2.4-million-year-old artifacts and stone tool-cutmarked bones from Ain Boucherit, Algeria. Science 362 (1297). https://doi.org/10.1126/science.aau0008.

Scarin, E., 1937. Insediamenti e tipi di dimore, in: reale Società Geografica Italiana (Ed.). In: Il Sahara Italiano, Fezzan e Oasi di Gat. Italiana Arti Grafiche, Roma, Societa', pp. 515-560. 
Sureda, P., Camarós, E., Cueto, M., Teira, L.C., Aceituno, F.J., Albero, D., ÁlvarezFernández, E., Bofill, M., López-Dóriga, I., Marín, D., Masclans, A., Picornell, L., Revelles, J., Burjachs, F., 2017. Surviving on the isle of Formentera (Balearic Islands): Adaptation of economic behaviour by Bronze Age first settlers to an extreme insular environment. J. Archaeolog. Sci.: Rep. 12, 860-875.

Tabucco, A., Zomer, R., 2019. Global Aridity Index and Potential Evapotranspiration (ET0) Climate Database v2. figshare. Fileset. 10.6084/m9.figshare.7504448.v3.

Tarradell, M., 1957-1958.. Caf Taht el Gar, cueva neolítica en la región de Tetuán (Marruecos). Ampurias 19-20, 137-166.

Tinthoin, R., 1946. La colonisation et l'évolution des genres de vie dans la région ouest d'Oran, de 1830 à 1885. L'information géographique 10 (4), 166-168.
Zapata, L., López-Sáez, J.A., Ruiz-Alonso, M., Linstädter, J., Pérez-Jordà, G., Morales, J., Kehl, M., Peña-Chocarro, L., 2013. Holocene environmental change and human impact in NE Morocco: Palaeobotanical evidence from Ifri Oudadane. The Holocene 23, 1286-1296. https://doi.org/10.1177/0959683613486944.

Zomer, R.J., Bossio, D.A., Trabucco, A., Yuanjie, L., Gupta, D.C., Singh, V.P., 2007. Trees and Water: Smallholder Agroforestry on Irrigated Lands in Northern India., IWMI Research Report 122. International Water Management Institute., Colombo, Sri Lanka.

Zomer, R.J., Trabucco, A., Bossio, D.A., van Straaten, O., Verchot, L.V., 2008. Climate Change Mitigation: A Spatial Analysis of Global Land Suitability for Clean Development Mechanism Afforestation and Reforestation. Agric. Ecosyst. Environ. 126, 67-80. 